\title{
Bifunctional [c2]Daisy-Chains and Their Incorporation into Mechanically Interlocked Polymers
}

\author{
Erin N. Guidry, Jean Li, J. Fraser Stoddart and Robert H. Grubbs* \\ Contribution from the Arnold and Mabel Beckman Laboratory of Chemical Synthesis, Division of \\ Chemistry and Chemical Engineering, California Institute of Technology, Pasadena, CA 91125, and \\ California NanoSystems Institute \& Department of Chemistry and Biochemistry, University of \\ California, Los Angeles, 405 Hilgard Avenue, Los Angeles, California 90095 \\ rhg@caltech.edu and stoddart@chem.ucla.edu
}

\section{Supporting Information}

Experimental procedures and characterization data $\left({ }^{1} \mathrm{H}\right.$ and ${ }^{13} \mathrm{C}$ NMR, HRMS $)$ for all compounds and their precursors.

General Experimental Section. NMR spectra were recorded on an Oxford $300 \mathrm{MHz}$ or $500 \mathrm{MHz}$ NMR spectrometer running Varian VNMR software. Chemical shifts are reported in parts per million $(\mathrm{ppm})$ with reference to internal solvent. Multiplicities are abbreviated as follows: singlet (s), doublet (d), triplet (t), quartet (q), quintet (quint), multiplet (m), and broad (br). High-resolution mass spectra (EI, MALDI and FAB) were provided by California Institute of Technology Mass Spectrometry Facility. Molecular mass calculations were performed with ChemDraw Ultra 9 (Cambridge Scientific). Analytical thin-layer chromatography (TLC) was performed using silica gel 60 F254 precoated plates $(0.25 \mathrm{~mm}$ thickness $)$ with a fluorescent indicator. Visualization was performed using UV and iodine stain. Flash column chromatography was performed using silica gel 60 (230-400 mesh) 
from EM Science. Grubbs 2nd Generation catalyst $\left(\mathrm{H}_{2} \mathrm{IMes}\right)(\mathrm{PCy})_{3}(\mathrm{Cl})_{2} \mathrm{Ru}=\mathrm{CHPh}(2)$ was obtained from Materia. All other chemicals were purchased from Aldrich or Acros Chemical Companies and used as obtained unless noted otherwise. Tetrahydrofuran and dichloromethane were purified and dried by passage through a solvent column. ${ }^{\text {ii }}$ Anhydrous dimethyl formamide was purchased in Acros seal bottles from Acros and used as received. Reverse-phase high pressure liquid chromatography (HPLC) was conducted using Gemini 5 micron c-18 column under a steady ramp (10\% MeCN in $0.1 \%$ aqueous trifluoroacetic acid to $100 \% \mathrm{MeCN}$ ) with UV detection at $254 \mathrm{~nm}$ using a Beckman System Gold detector. Gel permeation chromatography (GPC) was determined on an HPLC type system, using a Shimadzu LC-10AD pump, a rheodyne model 7125 injector with a $100 \mathrm{uL}$ loop, PLgel 5 um 10E3A size exclusion column and PLgel 5um guard column (purchased from polymer laboratories) connected in series with a Alltech on-line degassing system, a Wyatt Technology optilab DSP differential refractometer and a Wyatt Technology Dawn EOS multi angle laser light scattering (MALLS) detector. Astra V was used to analyze the raw MALLS and RI data. The elutent (DMF with $0.1 \mathrm{M} \mathrm{NH}_{4} \mathrm{PF}_{6}$ ) was prepared using HPLC grade DMF (purchased from Fischer Scientific) and $\mathrm{NH}_{4} \mathrm{PF}_{6}$ (purchased from Aldrich), which was filtered through a 0.45 micron filter before use. The flow rate was set to $0.5 \mathrm{~mL} / \mathrm{min}$. Instrument normalization and calibration was performed using a $30 \mathrm{~K}$ Polystyrene standard with a PDI $=1.06$ (purchased from Pressure Chemical Company). No calibration standards were used in determination of molecular weights or polydispersities. The $d n / d c$ values were obtained for each injection assuming $100 \%$ mass elution from the columns. These values were verified by measuring $d n / d c$ independently using a Wyatt optilab differential refractometer. 


\section{Experimental Section}

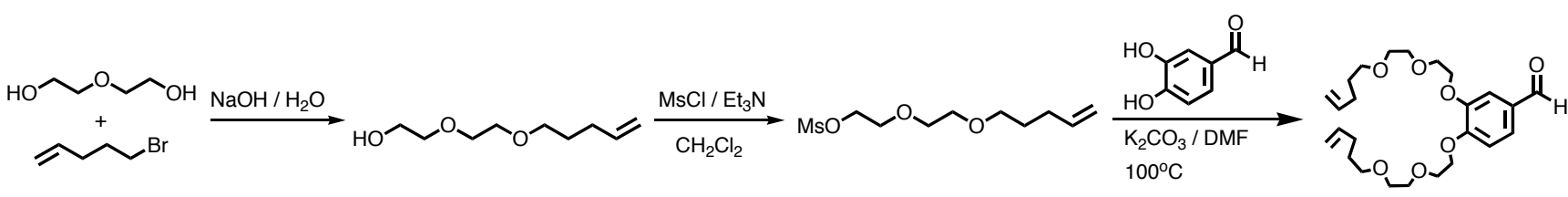

$1 a$

$1 b$

$1 c$

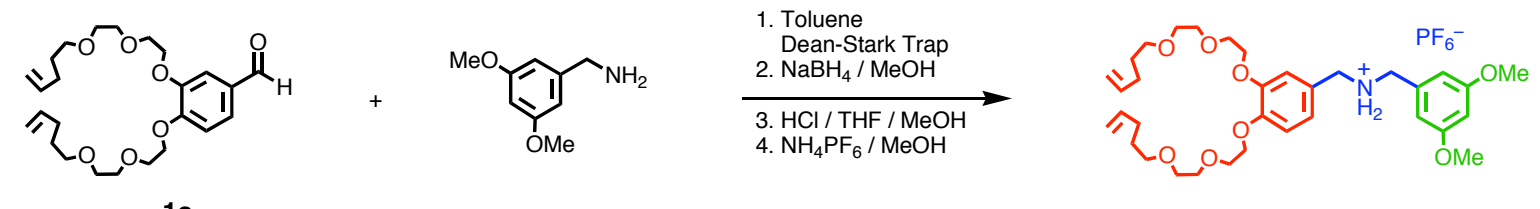

$1 c$
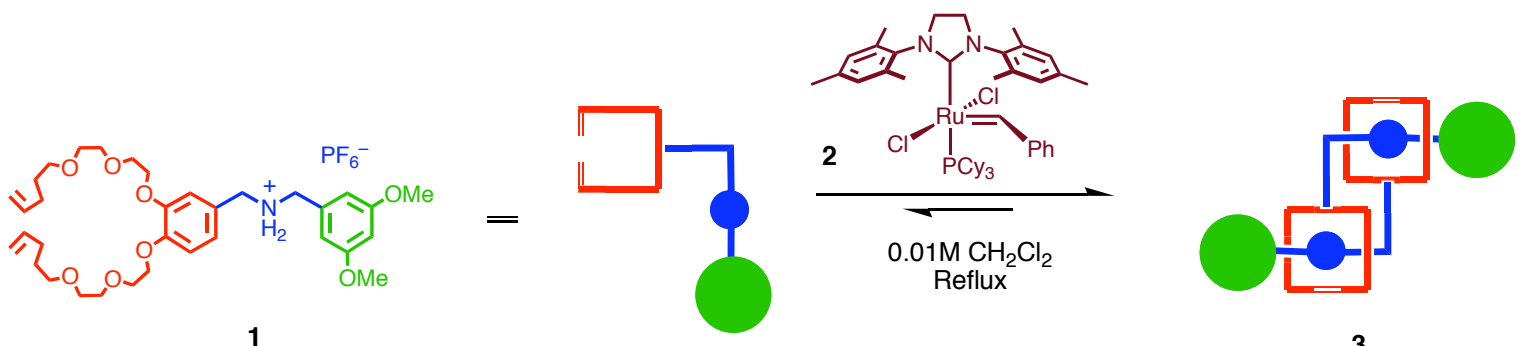

3

手

$1 b$

$5 a$

$5 b$

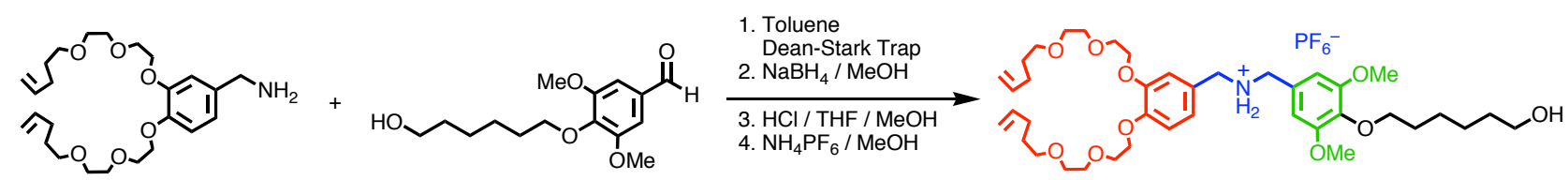

$5 b$

$5 c$

5

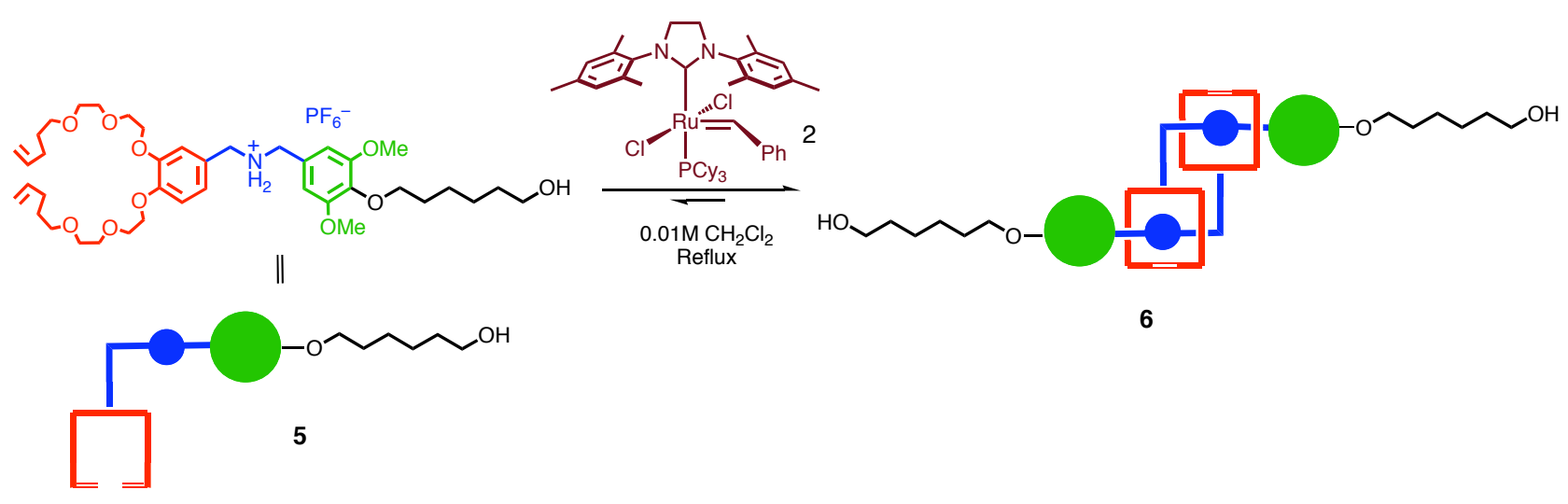



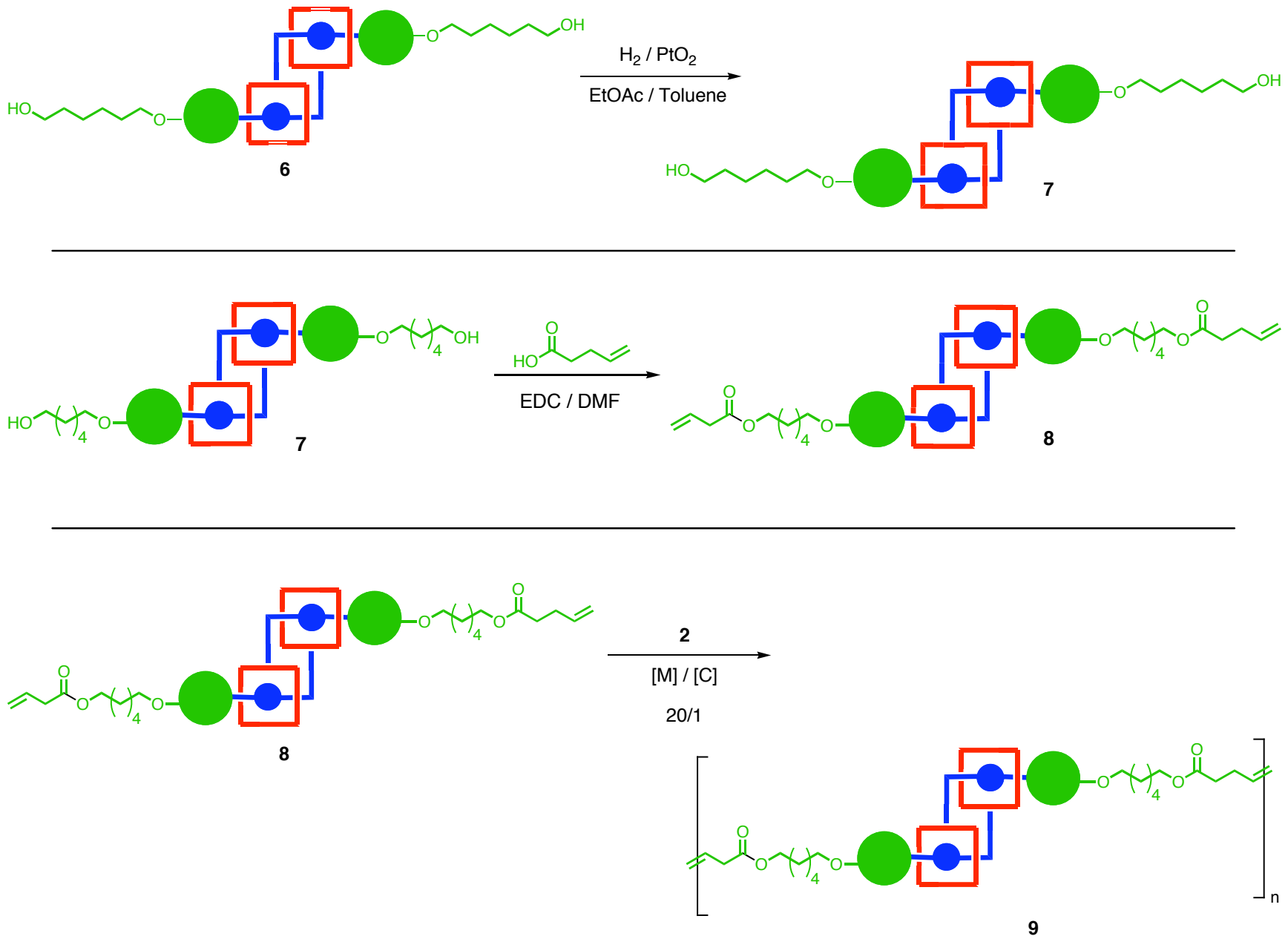

\section{Experimental Procedures:}

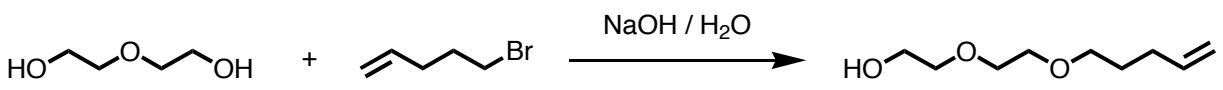

1a: A solution of diethylene glycol ( $320 \mathrm{ml}, 3.35$ moles), 5-bromo-1-pentene (50 g, 0.335 moles) and $\mathrm{H}_{2} \mathrm{O}$ containing $\mathrm{NaOH}\left(67 \mathrm{~g}, 1.72\right.$ moles, in $\left.67 \mathrm{ml} \mathrm{H}_{2} \mathrm{O}\right)$ was heated at $80{ }^{\circ} \mathrm{C}$ for 12 hours. The reaction mixture was diluted with water and washed with methylene chloride three times to give a crude product, which was purified by column chromatography $\left(\mathrm{SiO}_{2}\right.$ : hexanes/ethyl acetate $\left.4: 1\right)$ to yield the monoalkylated product as a colorless oil (36 g, 62\% yield). Characterization for this compound has been reported previously (Badjic', J. D., Cantrill, S. J., Grubbs, R. H.; Guidry, E. N.; Orenes, R.; Stoddart, J. F. Angew. Chem. Int. Ed. 2004, 43, 3273-3278.). 


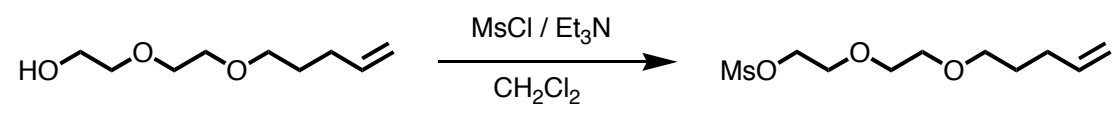

1b: The monoalkylated product 1a (36 g, 0.207 moles) and triethylamine ( $43 \mathrm{ml}, 0.306$ moles) were dissolved in $\mathrm{CH}_{2} \mathrm{Cl}_{2}(500 \mathrm{ml}, 0.4 \mathrm{M})$ and cooled to $0{ }^{\circ} \mathrm{C}$. A solution of mesyl chloride (24.3 ml, 0.207 moles $)$ in $\mathrm{CH}_{2} \mathrm{Cl}_{2}(50 \mathrm{ml})$ was added slowly. The reaction was gradually warmed to room temperature and stirred overnight. The reaction mixture was diluted with brine and washed with methylene chloride three times, to give a crude product, which was purified by column chromatography $\left(\mathrm{SiO}_{2}\right.$ : hexanes/ethyl acetate 2:1) to yield $\mathbf{1 b}$ as a colorless oil (51 g, $98 \%$ yield). ${ }^{1} \mathrm{H}$ NMR (300 MHz, $\left.\mathrm{CDCl}_{3}\right): \delta 5.70(\mathrm{~m}$, center, $1 \mathrm{H}), 4.95-4.83(\mathrm{br} \mathrm{m}, 2 \mathrm{H}), 4.29-4.26(\mathrm{~m}, 2 \mathrm{H}), 3.68-3.65(\mathrm{~m}, 2 \mathrm{H}), 3.65-3.61$ $(\mathrm{m}, 2 \mathrm{H}), 3.57-3.53(\mathrm{~m}, 2 \mathrm{H}), 3.49-3.45(\mathrm{~m}, 2 \mathrm{H}), 3.37(\mathrm{t}, \mathrm{J}=10.2 \mathrm{~Hz}, 2 \mathrm{H}), 2.99(\mathrm{~s}, 3 \mathrm{H}), 2.04-1.96(\mathrm{~m}$, $2 \mathrm{H}$ ), 1.56 (quint, $\mathrm{J}=6.6 \mathrm{~Hz}, 2 \mathrm{H}) .{ }^{13} \mathrm{C} \mathrm{NMR}\left(75 \mathrm{MHz}, \mathrm{CDCl}_{3}\right): \delta 138.10,114.72,70.55,69.92,69.45$, 68.90, 52.57, 37.54, 30.11, 28.67. HRMS-FAB (m/z): $[\mathrm{M}+\mathrm{H}]$ calcd for $\mathrm{C}_{10} \mathrm{H}_{21} \mathrm{O}_{5} \mathrm{~S}, 253.1110$; found, 253.1113.

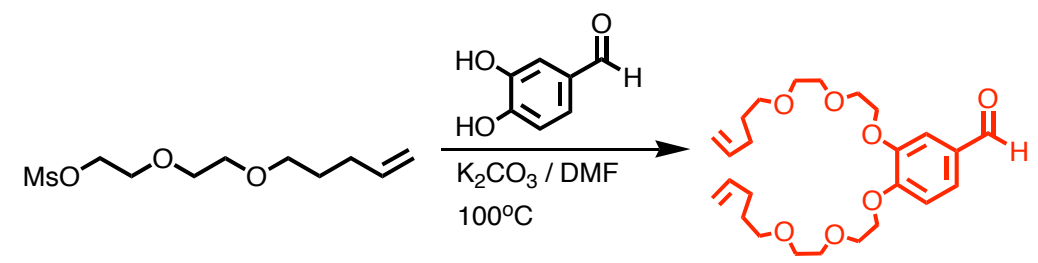

1c: Compound 1b (37.1 g, 0.147 moles), 3,4-dihydroxybenzaldehyde (9.67 g, 0.0699 moles), and potassium carbonate ( $29 \mathrm{~g}, 0.210$ moles) were suspended in anhydrous DMF (500 ml, $0.3 \mathrm{M})$. The reaction mixture was heated to $80{ }^{\circ} \mathrm{C}$ and stirred for 3 days. The reaction mixture was diluted with water and washed with ethyl acetate three times to give a crude product, which was purified by column chromatography $\left(\mathrm{SiO}_{2}\right.$ : hexanes/ethyl acetate 1:1) to yield the alkylated product as an orange oil (28 $\mathrm{g}$, $91 \%$ yield). ${ }^{1} \mathrm{H}$ NMR (300 MHz, $\left.\mathrm{CDCl}_{3}\right): \delta 9.83(\mathrm{~s}, 1 \mathrm{H}), 7.45-7.42(\mathrm{~m}, 2 \mathrm{H}), 7.00(\mathrm{~d}, \mathrm{~J}=8.7 \mathrm{~Hz}, 1 \mathrm{H})$, 5.87-5.73 (m, 2H), 5.04-4.92 (m, 4H), 4.23 (quint, $\mathrm{J}=4.8 \mathrm{~Hz}, 4 \mathrm{H}), 3.90$ (q, J = 5.4 Hz, 4H), 3.75-3.72 $(\mathrm{m}, 4 \mathrm{H}), 3.61-3.58(\mathrm{~m}, 4 \mathrm{H}), 3.47(\mathrm{t}, \mathrm{J}=6.6 \mathrm{~Hz}, 4 \mathrm{H}), 2.10(\mathrm{q}, \mathrm{J}=7.8 \mathrm{~Hz}, 4 \mathrm{H}), 1.67$ (quint, $\mathrm{J}=6.9 \mathrm{~Hz}$, $4 \mathrm{H}) .{ }^{13} \mathrm{C} \mathrm{NMR}\left(75 \mathrm{MHz}, \mathrm{CDCl}_{3}\right): \delta 191.04,154.51,149.34,138.41,138.37,130.39,126.84,114.91$, $114.88,112.65,112.07,71.18,71.10,70.92,70.34,69.71,69.59,68.90,68.85,30.38,28.91$. HRMSFAB (m/z): $[\mathrm{M}+\mathrm{H}]$ calcd for $\mathrm{C}_{25} \mathrm{H}_{39} \mathrm{O}_{7}, 451.2696$; found, 451.2713.

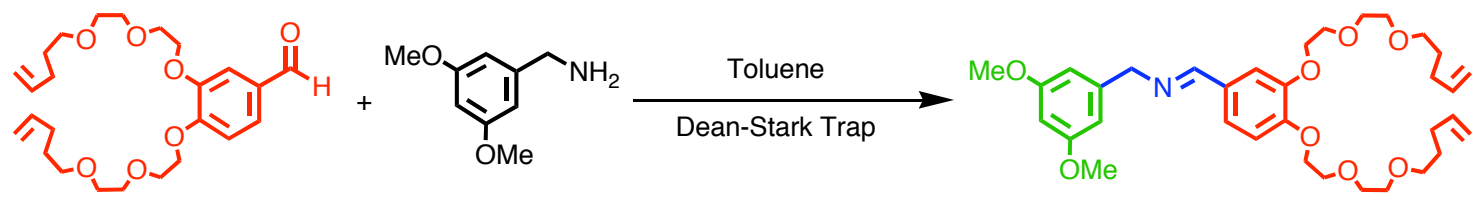

1: Compound 1c (3 g, 6.66 mmoles) and 3,5-dimethoxy benzylamine (1.11 g, 6.66 mmoles) were dissolved in toluene $(70 \mathrm{ml}, 0.1 \mathrm{M})$. The reaction was heated under reflux for 12 hours using a DeanStark apparatus. The solvent was evaporated under reduced pressure to give the crude immine as an orange oil (3.99 g). This product was immediately used in the next step without purification. 


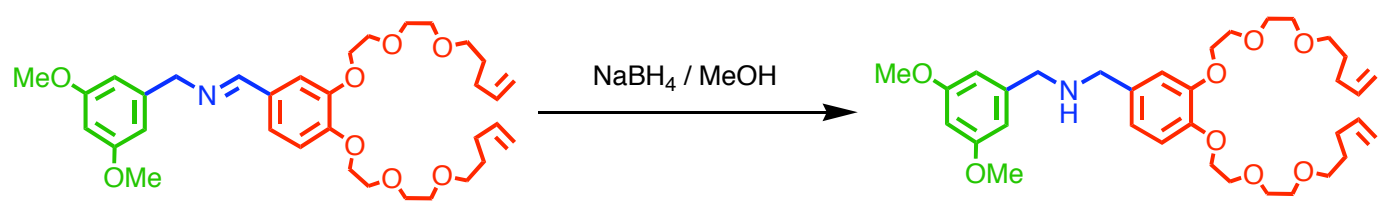

The imine (3.99 g, 6.66 mmoles) was dissolved in $\mathrm{MeOH}(67 \mathrm{ml}, 0.1 \mathrm{M})$. After portion-wise addition of sodium borohydride $(0.78 \mathrm{~g}, 19.98 \mathrm{mmoles})$, the reaction mixture was stirred for 4 hours. The solvent was evaporated under reduced pressure and the crude residue was partitioned between $\mathrm{CH}_{2} \mathrm{Cl}_{2}$ $(200 \mathrm{ml})$ and $2 \mathrm{M} \mathrm{NaOH}$ solution $(200 \mathrm{ml})$. The aqueous layer was further washed with $\mathrm{CH}_{2} \mathrm{Cl}_{2}(200$ $\mathrm{ml}$ ). The organic phases were combined and washed with $\mathrm{NaCl}$ (sat.) and dried over $\mathrm{MgSO}_{4}$. Filtration, followed by evaporation gave the crude product, an orange oil (3.8 g) which was used in the next step without further purification.

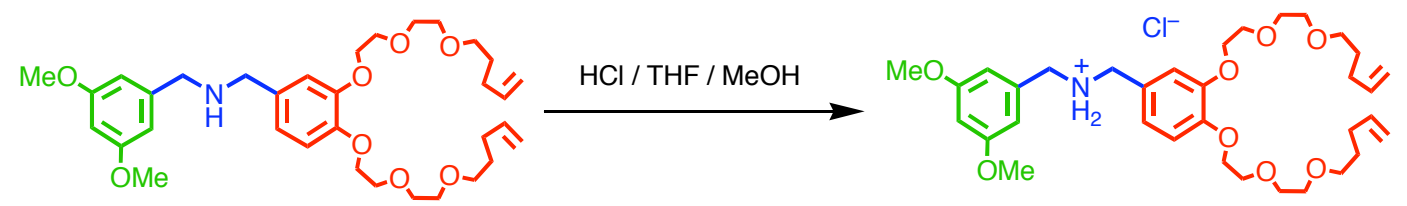

The amine (3.8 g, 6.33 mmoles) was dissolved in a solution of $100 \mathrm{ml}$ of THF, $20 \mathrm{ml}$ of $\mathrm{MeOH}$ and 2 $\mathrm{ml}$ of $1 \mathrm{M} \mathrm{HCl}$. The reaction mixture was stirred for 1 hour. The THF and $\mathrm{MeOH}$ were removed under reduced pressure. The crude mixture was partitioned between water and $\mathrm{CH}_{2} \mathrm{Cl}_{2}$. The organic layer was extracted twice more with water. The organic layer was dried over magnesium sulfate, filtered and the solvent was removed under reduced pressure to yield an orange solid. The solid was purified by washing with cold ether $(2 \mathrm{X}, 20 \mathrm{ml})$ to yield a white solid $(3.74 \mathrm{~g})$. The solid was used in the next step without any further purification.

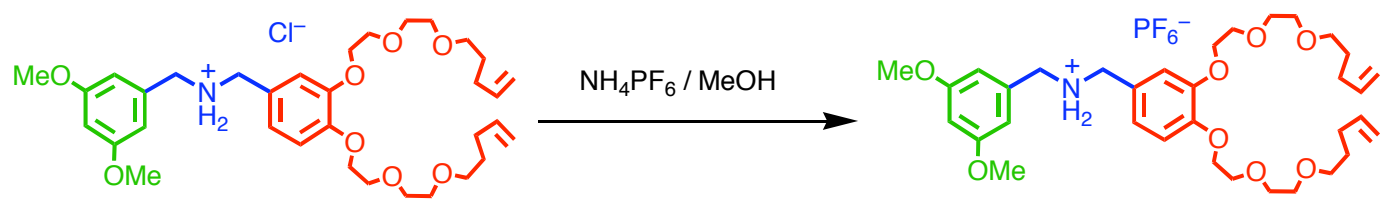

1-H·PF : The chloride salt (3.74 g, 5.88 mmoles) and ammonium hexafluorophosphate (1.91 g, 11.76 mmoles) were dissolved in $\mathrm{MeOH}(60 \mathrm{ml}, 0.1 \mathrm{M})$. The reaction was stirred at room temperature for 4 hours. The solvent was removed under reduced pressure. The crude mixture was partitioned between $\mathrm{CH}_{2} \mathrm{Cl}_{2}$ and water. The organic layer was washed two times and dried over magnesium sulfate. The solvent was removed under reduced pressure to yield a sticky pale yellow solid (3.69 g, $84 \%$ yield). ${ }^{1} \mathrm{H} \mathrm{NMR}\left(300 \mathrm{MHz}, \mathrm{CDCl}_{3}\right): \delta 7.59$ (broad s, 2H), $6.93(\mathrm{~d}, \mathrm{~J}=7.8 \mathrm{~Hz}, 1 \mathrm{H}), 6.79-6.75(\mathrm{~m}, 2 \mathrm{H}), 6.67$ $(\mathrm{m}, 2 \mathrm{H}), 6.44(\mathrm{~s}, 1 \mathrm{H}), 5.77-5.64(\mathrm{~m}, 2 \mathrm{H}), 4.95-4.88(\mathrm{~m}, 4 \mathrm{H}), 4.43(\mathrm{~m}, 2 \mathrm{H}), 4.23(\mathrm{~m}, 2 \mathrm{H}), 4.01(\mathrm{~s}, 4 \mathrm{H})$, $3.74(\mathrm{~s}, 6 \mathrm{H}), 3.65-3.61(\mathrm{~m}, 12 \mathrm{H}), 3.50-3.42(\mathrm{~m}, 4 \mathrm{H}), 2.07-1.98(\mathrm{~m}, 4 \mathrm{H}), 1.61($ hex, $\mathrm{J}=6.9 \mathrm{~Hz}, 4 \mathrm{H}) .{ }^{13} \mathrm{C}$ NMR $\left(75 \mathrm{MHz}, \mathrm{CDCl}_{3}\right): \delta 161.48,147.35,146.64,137.79,137.72,133.43,123.76,123.43,115.30$, 
115.25, 114.86, 114.10, 113.14, 106.49, 100.76, 71.83, 71.59, 71.03, 70.94, 70.84, 70.16, 70.07, 69.79, 69.58, 68.83, 68.12, 55.61, 52.54, 52.31, 30.16, 28.70, 28.66. HRMS-FAB (m/z): [M + e] calcd for $\mathrm{C}_{34} \mathrm{H}_{52} \mathrm{NO}_{8}, 602.3693$; found, 602.3690 .

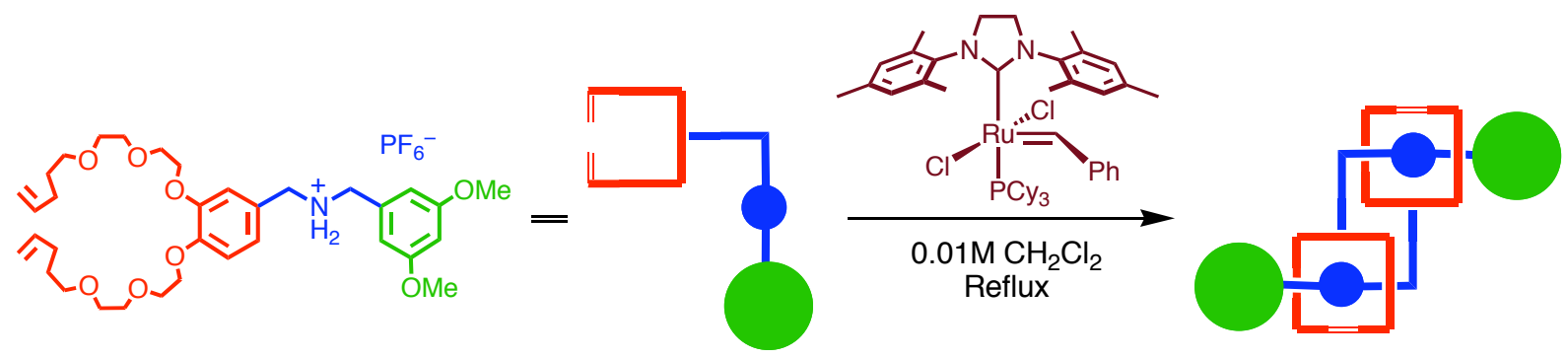

3-H $\cdot \mathrm{PF}_{6}$ : Compound 1- $\mathrm{H} \cdot \mathrm{PF}_{6}\left(3 \mathrm{~g}, 4.02\right.$ mmoles) was dissolved in anhydrous, degassed $\mathrm{CH}_{2} \mathrm{Cl}_{2}(400$ $\mathrm{ml}, 0.01 \mathrm{M})$. The catalyst $\left(\mathrm{H}_{2} \mathrm{IMes}\right)\left(\mathrm{PCy}_{3}\right)(\mathrm{Cl})_{2} \mathrm{Ru}=\mathrm{CHPh} 2(0.170 \mathrm{~g}, 0.201 \mathrm{mmoles})$ was added under a dry $\mathrm{Ar}$ atmosphere and the reaction was heated to $40{ }^{\circ} \mathrm{C}$ for $12 \mathrm{~h}$. The reaction quenched by addition of ethyl vinyl ether. The reaction was stirred for an additional 30 minutes at $40^{\circ} \mathrm{C}$. The reaction mixture was cooled to room temperature. The solvent was removed under reduced pressure and the crude oil was purified by column chromatography $\left(\mathrm{SiO}_{2}\right.$ : methylene chloride/methanol 100:1 gradient to 100:2) to yield the daisy chain dimer $3-\mathrm{H} \cdot \mathrm{PF}_{6}$ as a pale brown foamy solid (2.74 g, $95 \%$ yield). ${ }^{1} \mathrm{H}$ NMR (300 MHz, $\left.\mathrm{CDCl}_{3}\right): \delta$ 6.94-6.91 (m, 2H), 6.85-6.80 (m, 2H), 6.72-6.66 (m, 6H), 6.48-6.46 (m, $2 \mathrm{H})$, 5.46-5.32 (m, 4H), 4.68-4.25 (broad m, $16 \mathrm{H}), 3.85-3.47(\mathrm{~m}, 28 \mathrm{H}), 2.33-2.26(\mathrm{~m}, 8 \mathrm{H}), 2.09-1.96$ $(\mathrm{m}, 4 \mathrm{H}), 1.78-1.48(\mathrm{~m}, 4 \mathrm{H}) .{ }^{13} \mathrm{C} \mathrm{NMR}\left(75 \mathrm{MHz}, \mathrm{CDCl}_{3}\right): \delta 161.62,146.94,146.48,133.91,133.74$, $131.23,130.99$, 129.95, 129.63, 123.80, 123.65, 113.71, 112.86, 112.62, 106.55, 106.46, 105.64, $100.48,72.901,72.45,72.23,72.09,71.81,71.35,70.59,70.13,69.85,69.59,68.75,68.53,55.70$, $52.69,52.45,52.17,51.94,30.64,30.49,29.04,28.95,28.66,25.40,25.30$. HRMS-FAB (m/z): [M + e] calcd for $\mathrm{C}_{64} \mathrm{H}_{95} \mathrm{~N}_{2} \mathrm{O}_{16}, 1147.668$; found, 1147.661 .

Crystals suitable for X-ray analysis were grown by slow evaporation from EtOAc. Crystallization lead to fractional separation of the mesoform, which remained dissolved in the mother liquour. The racemic modification produced crystals suitable for X-ray analysis. Crystals of $4-\mathrm{H}_{2} \cdot 2 \mathrm{PF}_{6}$ diffract poorly and appear to be twinned. Data used for least-squares refinement was restricted to $2 \theta<40^{\circ}$ with data between $36-40^{\circ}$ being extremely weak. Disorder is observed in the ring-closed portion of the molecules. Restraints were placed on temperature factors, bond distances and bond angles in this portion of the molecules. The structure has been deposited in the CCDC; number xxxx. See the CIF file for complete details. 


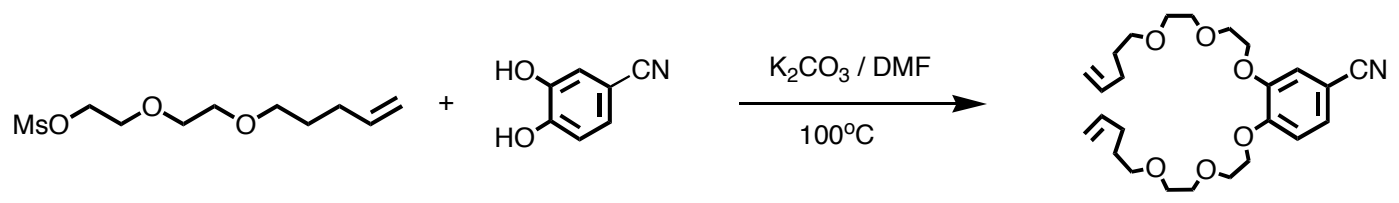

5a: Compound $\mathbf{1 b}$ (51 g, 0.202 moles), 3,4-dihydroxybenzonitrile (13 g, 0.963 moles), and potassium carbonate (40 g, 0.289 moles) were suspended in anhydrous DMF (500 ml, $2 \mathrm{M})$. The reaction mixture was heated to $80{ }^{\circ} \mathrm{C}$ and stirred for 3 days. The reaction mixture was diluted with water and washed with ethyl acetate three times to give a crude product, which was purified by column chromatography $\left(\mathrm{SiO}_{2}\right.$ : hexanes/ethyl acetate 3:1) to yield the alkylated product 5a as an orange oil (23 g, $53 \%$ yield). ${ }^{1} \mathrm{H}$ NMR $\left(300 \mathrm{MHz}, \mathrm{CDCl}_{3}\right): \delta 7.26-7.23(\mathrm{~m}, 1 \mathrm{H}), 7.15-7.14(\mathrm{~m}, 1 \mathrm{H}), 6.92(\mathrm{~d}, \mathrm{~J}=8.7$ $\mathrm{Hz}, 1 \mathrm{H}), 5.87-5.73(\mathrm{~m}, 2 \mathrm{H}), 5.04-4.93(\mathrm{~m}, 4 \mathrm{H}), 4.22-4.15(\mathrm{~m}, 4 \mathrm{H}), 3.88(\mathrm{qt}, \mathrm{J}=5.1 \mathrm{~Hz}, 4 \mathrm{H}), 3.71(\mathrm{~m}$, 4H), 3.59 (q, J = 3.3 Hz, 4H), 3.49-3.44 (m, 4H), $2.10(\mathrm{qt}, \mathrm{J}=7.2 \mathrm{~Hz}, 4 \mathrm{H}), 1.73-1.63(\mathrm{~m}, 4 \mathrm{H}) .{ }^{13} \mathrm{C}$ NMR (75 MHz, $\left.\mathrm{CDCl}_{3}\right)$ : $\delta 152.89,148.86,138.24,138.19,126.77,119.17,117.08,114.76,114.73$, 113.49, 104.10, 70.98, 70.96, 70.79, 70.77, 70.18, 70.16, 69.56, 69.42, 69.15, 68.69, 30.21, 28.74. HRMS-FAB (m/z): [M + H] calcd for $\mathrm{C}_{26} \mathrm{H}_{40} \mathrm{NO}_{6}, 462.2856$; found, 462.2857 .
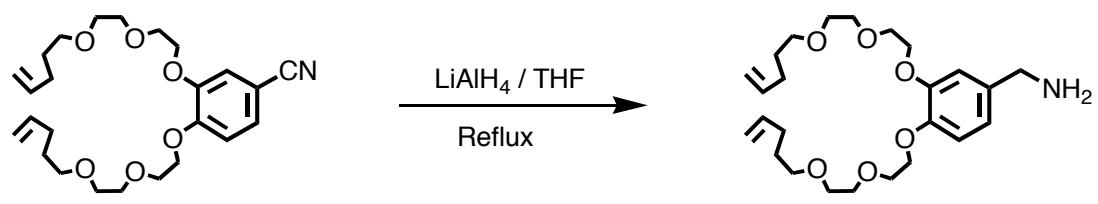

5b: The alkylated product 5a (23 g, 0.0515 moles) was dissolved in anhydrous THF (250 ml, $0.2 \mathrm{M})$ and cooled to $0{ }^{\circ} \mathrm{C}$, under an argon atmosphere. Lithium aluminum hydride $(5.9 \mathrm{~g}, 0.155$ moles $)$ was added slowly, piecewise, to the reaction mixture. The reaction was warmed to $76^{\circ} \mathrm{C}$ and refluxed under an argon atmosphere for 12 hours. The reaction was quenched by addition of $6 \mathrm{ml}$ of $\mathrm{H}_{2} \mathrm{O}$, followed by addition of $6 \mathrm{ml}$ of $\mathrm{NaOH}(\mathrm{aq})(15 \%)$ followed by addition of $18 \mathrm{ml}$ of $\mathrm{H}_{2} \mathrm{O}$. A large excess of celite was added and the mixture was filtered and then the solvent was removed under reduced pressure. The reaction mixture was diluted with methylene chloride and washed with water three times with water to yield compound $\mathbf{5 b}$ as a yellow oil (18 $\mathrm{g}, 78 \%$ yield). No further purification was necessary. ${ }^{1} \mathrm{H}$ NMR $\left(300 \mathrm{MHz}, \mathrm{CDCl}_{3}\right): \delta 6.89-6.80(\mathrm{~m}, 3 \mathrm{H}), 5.87-5.73(\mathrm{~m}, 2 \mathrm{H}), 5.04-4.92(\mathrm{~m}$, $4 \mathrm{H}), 4.19-4.13(\mathrm{~m}, 4 \mathrm{H}), 3.85$ (q, J = 5.4 Hz, 4H), 3.77 (s, 2H), 3.73-3.70 (m, 4H), 3.60-3.57 (m, 4H), $3.46(\mathrm{t}, 6.9 \mathrm{~Hz}, 4 \mathrm{H}), 2.10(\mathrm{q}, \mathrm{J}=6.9 \mathrm{~Hz}, 4 \mathrm{H}), 1.67$ (quint, $\mathrm{J}=6.9 \mathrm{~Hz}, 4 \mathrm{H}) .{ }^{13} \mathrm{C} \mathrm{NMR}\left(75 \mathrm{MHz}, \mathrm{CDCl}_{3}\right)$ : $\delta 149.20,147.91,138.40,120.02,115.18,114.85,114.00,70.97,70.87,70.32,69.93,69.24,69.04$, 46.27, 30.37, 28.90 . 


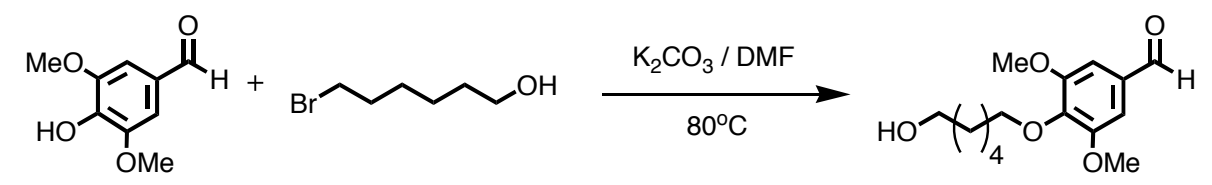

5c: Syringaldehyde (15 g, 0.0823 moles), 6-bromo-1-hexanol (17.9 g, 0.0989 moles), and potassium carbonate (34 g, 0.247 moles) were suspended in anhydrous DMF (0.2 M, $400 \mathrm{ml})$. The reaction mixture was heated to $80{ }^{\circ} \mathrm{C}$ and stirred for 2 days. The reaction mixture was diluted with water and washed with ethyl acetate three times to give a crude product, which was purified by column chromatography $\left(\mathrm{SiO}_{2}\right.$ : hexanes/ethyl acetate 3:2) to yield the alkylated product $\mathbf{5 c}$ as an orange oil (18.6 g, $80 \%$ yield). ${ }^{1} \mathrm{H}$ NMR $\left(300 \mathrm{MHz} \mathrm{CDCl}_{3}\right): \delta 9.85(\mathrm{~s}, 1 \mathrm{H}), 7.11(\mathrm{~s}, 2 \mathrm{H}), 4.06(\mathrm{t}, \mathrm{J}=6.6 \mathrm{~Hz}$, 2H), $3.90(\mathrm{~s}, 6 \mathrm{H}), 3.64(\mathrm{t}, \mathrm{J}=6.6 \mathrm{~Hz}, 4 \mathrm{H}), 1.77$ (quint, $6.6 \mathrm{~Hz}, 4 \mathrm{H}), 1.63-1.36(\mathrm{~m}, 6 \mathrm{H}) .{ }^{13} \mathrm{C}$ NMR $(75$ $\left.\mathrm{MHz}, \mathrm{CDCl}_{3}\right): \delta 191.36,154.03,147.96,143.11,131.71,106.88,73.67,62.99,56.40,32.84,30.20$, 25.71. HRMS-EI (m/z): [M + e] calcd for $\mathrm{C}_{15} \mathrm{H}_{22} \mathrm{O}_{5}, 282.1467$; found, 282.1459 .

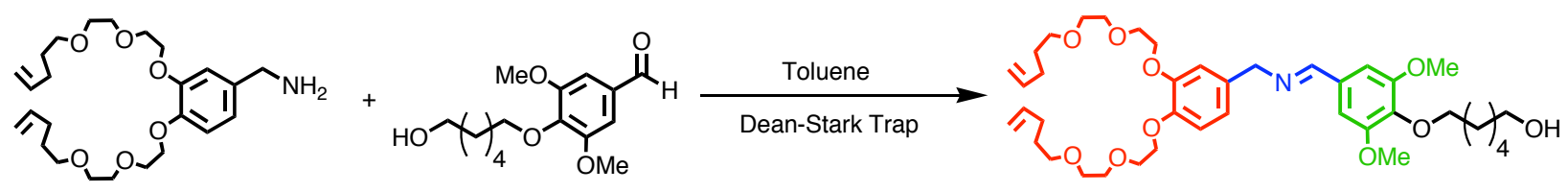

5: Compound 5b (18 g, 0.0399 moles) and compound 5c (11.25 g, 0.0399 moles) were dissolved in toluene $(400 \mathrm{ml}, 0.1 \mathrm{M})$. The reaction was heated under reflux for 12 hours using a Dean-Stark apparatus. The solvent was evaporated under reduced pressure to give the crude imine as an orange oil $(28.5 \mathrm{~g})$. This product was immediately used in the next step without purification.

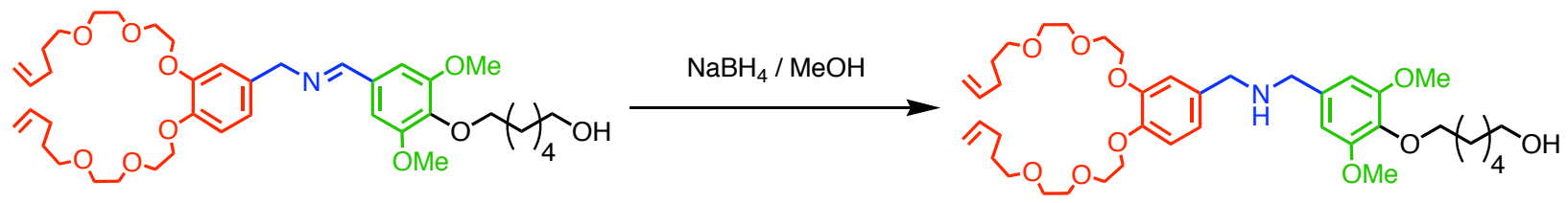

The imine (28.5 g, 0.0399 moles) was dissolved in $\mathrm{MeOH}$ (400 ml, 0.1 M). After portion-wise addition of sodium borohydride ( $4.5 \mathrm{~g}, 0.120$ moles), the reaction mixture was stirred for 4 hours. The solvent was evaporated under reduced pressure and the crude residue was partitioned between $\mathrm{CH}_{2} \mathrm{Cl}_{2}$ $(400 \mathrm{ml})$ and $2 \mathrm{M} \mathrm{NaOH}$ solution $(400 \mathrm{ml})$. The aqueous layer was further washed with $\mathrm{CH}_{2} \mathrm{Cl}_{2}(400$ $\mathrm{ml}$ ). The organic phases were combined and washed with $\mathrm{NaCl}$ (sat.) and dried over $\mathrm{MgSO}_{4}$. Filtration, followed by evaporation gave the crude product, an orange oil (28.5 g) which was used in the next step without further purification. 


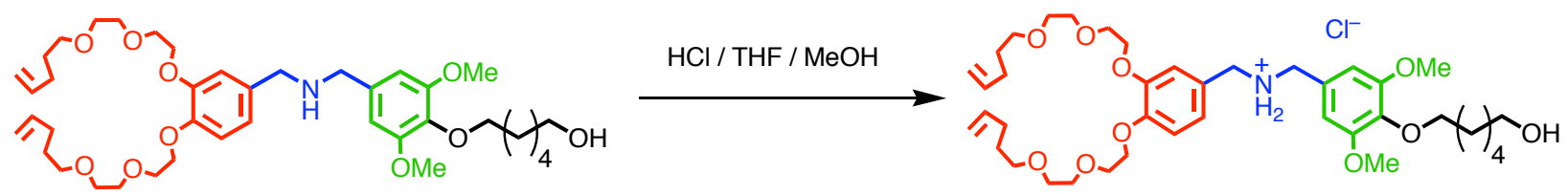

The amine (28.5 g, 0.399 moles) was dissolved in a solution of $200 \mathrm{ml}$ of THF, $40 \mathrm{ml}$ of $\mathrm{MeOH}$ and 5 $\mathrm{ml}$ of $1 \mathrm{M} \mathrm{HCl}$. The reaction mixture was stirred for 1 hour. The THF and $\mathrm{MeOH}$ were removed under reduced pressure. The crude mixture was partitioned between water and $\mathrm{CH}_{2} \mathrm{Cl}_{2}$. The organic layer was extracted twice more with water. The organic layer was dried over magnesium sulfate and the solvent was removed under reduced pressure to yield an orange solid. The solid was purified by washing with cold ether $(2 \mathrm{X}, 50 \mathrm{ml})$ to yield a white solid $(27.3 \mathrm{~g})$.

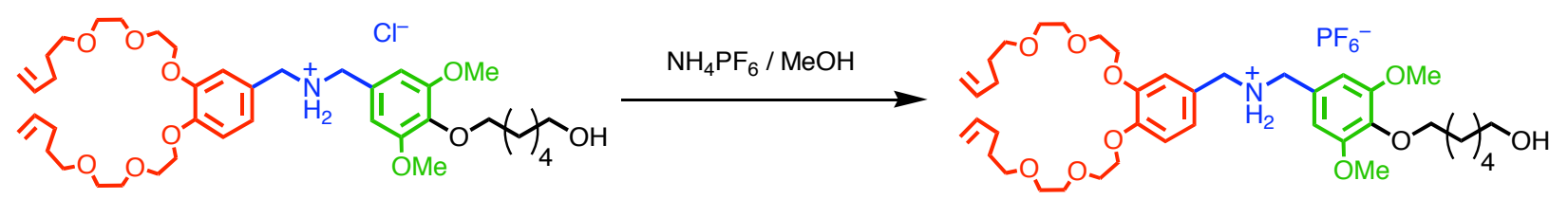

5-H·PF : The chloride salt (27.3 g, 0.0363 moles) and ammonium hexafluorophosphate (11.8 g, 0.0726 moles) were dissolved in $\mathrm{MeOH}(360 \mathrm{ml}, 0.1 \mathrm{M})$. The reaction was stirred at room temperature for 4 hours. The solvent was removed under reduced pressure. The crude mixture was partitioned between $\mathrm{CH}_{2} \mathrm{Cl}_{2}$ and water. The organic layer was washed two times and dried over magnesium sulfate. The solvent was removed under reduced pressure to yield $\mathbf{5}-\mathrm{H} \cdot \mathrm{PF}_{6}$ as a sticky pale yellow solid (26.6 $\mathrm{g}, 85$ $\%$ yield). ${ }^{1} \mathrm{H} \mathrm{NMR}\left(300 \mathrm{MHz}, \mathrm{CDCl}_{3}\right): \delta 7.38$ (broad s, $\left.2 \mathrm{H}\right), 6.95(\mathrm{~d}, \mathrm{~J}=8.1 \mathrm{~Hz}, 1 \mathrm{H}), 6.83-6.73(\mathrm{~m}$, $4 \mathrm{H}), 5.77-5.64(\mathrm{~m}, 2 \mathrm{H}), 4.95-4.88(\mathrm{~m}, 4 \mathrm{H}), 4.37(\mathrm{~s}, 2 \mathrm{H}), 4.24(\mathrm{~s}, 2 \mathrm{H}), 4.02(\mathrm{~s}, 4 \mathrm{H}), 3.87(\mathrm{t}, \mathrm{J}=6.3 \mathrm{~Hz}$, $2 \mathrm{H}), 3.77(\mathrm{~s}, 6 \mathrm{H}), 3.63-3.42(\mathrm{~m}, 16 \mathrm{H}), 2.01(\mathrm{~m}, 4 \mathrm{H}), 1.62$ (quint, $\mathrm{J}=6.9 \mathrm{~Hz}, 6 \mathrm{H}), 1.55-1.45(\mathrm{~m}, 2 \mathrm{H})$, $1.38-1.31(\mathrm{~m}, 4 \mathrm{H}) \cdot{ }^{13} \mathrm{C}$ NMR $\left(75 \mathrm{MHz} \mathrm{CDCl}_{3}\right): \delta 153.94,147.49,146.80,137.79,137.75,126.43$, $123.73,123.65,115.30,115.26,114.10,113.08,106.14,73.45,71.48,71.20,71.04,70.97,69.96$, 69.91, 69.48, 69.36, 68.56, 68.00, 62.81, 65.38, 52.65, 52.40, 32.68, 30.14, 29.96, 28.63, 25.61, 25.53. HRMS-FAB (m/z): $[\mathrm{M}+\mathrm{H}]$ calcd for $\mathrm{C}_{40} \mathrm{H}_{64} \mathrm{NO}_{10}, 718.4530$; found, 718.4505. 


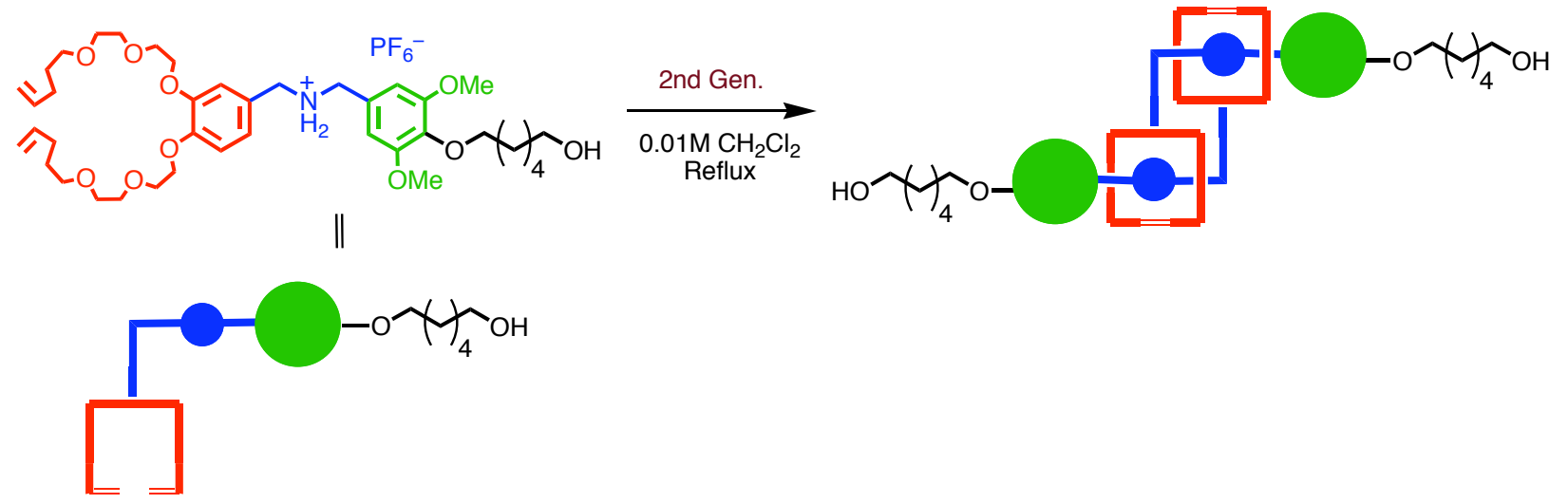

6- $-\mathrm{H}_{2} \cdot 2 \mathrm{PF}_{6}$ : Compound 5- $\mathrm{H} \cdot \mathrm{PF}_{6}(3 \mathrm{~g}, 0.00359$ moles $)$ was dissolved in anhydrous, degassed $\mathrm{CH}_{2} \mathrm{Cl}_{2}$ $(360 \mathrm{ml}, 0.01 \mathrm{M})$. The catalyst $\left(\mathrm{H}_{2} \mathrm{IMes}\right)\left(\mathrm{PCy}_{3}\right)(\mathrm{Cl})_{2} \mathrm{Ru}=\mathrm{CHPh} 2(0.147 \mathrm{~g}, 0.174 \mathrm{mmoles})$ was added under a dry Ar atmosphere and the reaction was heated to $40{ }^{\circ} \mathrm{C}$ for $12 \mathrm{~h}$. The reaction quenched by addition of ethyl vinyl ether. The reaction was stirred for an additional 30 minutes at $40^{\circ} \mathrm{C}$. The reaction mixture was cooled to room temperature. The solvent was removed under reduced pressure and the crude oil was purified by column chromatography $\left(\mathrm{SiO}_{2}\right.$ : methylene chloride/methanol 100:1 gradient to 100:2) to yield the product $6-\mathrm{H}_{2} \cdot 2 \mathrm{PF}_{6}$ as a pale brown foamy solid $\left(2.84 \mathrm{~g}, 98 \%\right.$ yield). ${ }^{1} \mathrm{H}$ NMR (300 MHz, $\mathrm{CDCl}_{3}$ ): $\delta 7.75$ (br s, 4H), 6.99-6.75 (m, 10H), 5.44 (br m, 4H), 4.63-4.31 (br m, $12 \mathrm{H}), 4.00(\mathrm{t}, \mathrm{J}=6.9 \mathrm{~Hz}, 8 \mathrm{H}), 3.83(\mathrm{~s}, 6 \mathrm{H}), 3.82(\mathrm{~s}, 6 \mathrm{H}), 3.68-3.50(\mathrm{br} \mathrm{m}, 36 \mathrm{H}), 2.32(\mathrm{~m}, 2 \mathrm{H}), 2.12$ $(\mathrm{m}, 8 \mathrm{H}), 1.79-1.35(\mathrm{~m}, 24 \mathrm{H}) .{ }^{13} \mathrm{C} \mathrm{NMR}\left(75 \mathrm{MHz}, \mathrm{CDCl}_{3}\right): \delta 153.94,147.49,146.80,137.79,137.75$, 126.43, 123.73, 123.65, 115.30, 115.26, 114.10, 113.08, 73.62, 73.00, 72.69, 72.43, 72.29, 72.01, 71.58, 71.02, 70.50, 69.95, 68.63, 68.39, 63.05, 56.59, 52.69, 52.36, 32.83, 31.12, 30.18, 29.90, 29.78, 29.56, 27.95, 26.04, 25.77, 25.60. HRMS-FAB (m/z): $\left[\mathrm{M}+\mathrm{H}+\mathrm{PF}_{6}\right]$ calcd for $\mathrm{C}_{76} \mathrm{H}_{120} \mathrm{~N}_{2} \mathrm{O}_{20} \mathrm{~F}_{6} \mathrm{P}$, 1526.7346 ; found, 1525.8044 .

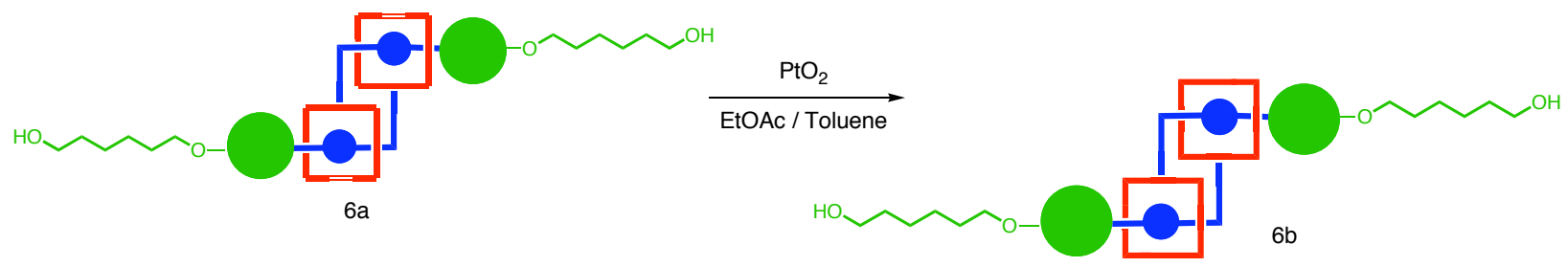

7- $\mathrm{H}_{2} \cdot 2 \mathrm{PF}_{6}$ : Compound 6- $\mathrm{H}_{2} \cdot 2 \mathrm{PF}_{6}(0.25 \mathrm{~g}, 0.150 \mathrm{mmoles})$ was dissolved in ethyl acetate $(0.001 \mathrm{M}, 150$ $\mathrm{ml}$ ). $\mathrm{PtO}_{2}$ (Adam's catalyst, $1.70 \mathrm{~g}, 0.0075 \mathrm{mmoles}$ ) was added and the reaction atmosphere was flushed with hydrogen for 5 minutes. An atmosphere of hydrogen was placed over the reaction using a balloon, and it was vigorously stirred a room temperature for 30 minutes. The reaction was filtered through a pad of celite and solvent removed under reduced pressure to yield $7-\mathrm{H}_{2} \cdot 2 \mathrm{PF}_{6}$ as a light brown sticky solid (0.24 g, $97 \%$ yield). ${ }^{1} \mathrm{H}$ NMR $\left(300 \mathrm{MHz}, \mathrm{CDCl}_{3}\right): \delta 7.75(\mathrm{br} \mathrm{s}, 4 \mathrm{H}), 7.01-6.77(\mathrm{~m}, 10 \mathrm{H})$, 4.63-4.33 (br m, 12H), 4.00 (t, J = 6.6 Hz, 8H), 3.83 (s, 12H), 3.74-3.50 (br m, 36H), $2.20(\mathrm{~m}, 8 \mathrm{H})$, $1.79-1.26(\mathrm{br} \mathrm{m}, 24 \mathrm{H}), 0.882-0.83(\mathrm{~m}, 8 \mathrm{H}) .{ }^{13} \mathrm{C} \mathrm{NMR}\left(75 \mathrm{MHz}, \mathrm{CDCl}_{3}\right): \delta 154.23,154.10,146.92$, $146.43,138.07,126.86,123.90,123.70,113.82,112.54,105.643,105.13,73.68,73.01,72.71,72.45$, 72.28, 72.08, 71.53, 71.06, 70.53, 69.97, 68.64, 68.39, 63.05, 56.59, 52.69, 52.36, 32.83, 31.12, 30.18, 29.90, 29.78, 29.56, 27.95, 26.04, 25.77, 25.69, 22.89, 14.33, 1.22. HRMS-FAB (m/z): $\left[\mathrm{M}+\mathrm{H}+\mathrm{PF}_{6}\right]$ calcd for $\mathrm{C}_{76} \mathrm{H}_{124} \mathrm{~N}_{2} \mathrm{O}_{20} \mathrm{~F}_{6} \mathrm{P}, 1529.8389$; found, 1529.8329 . 


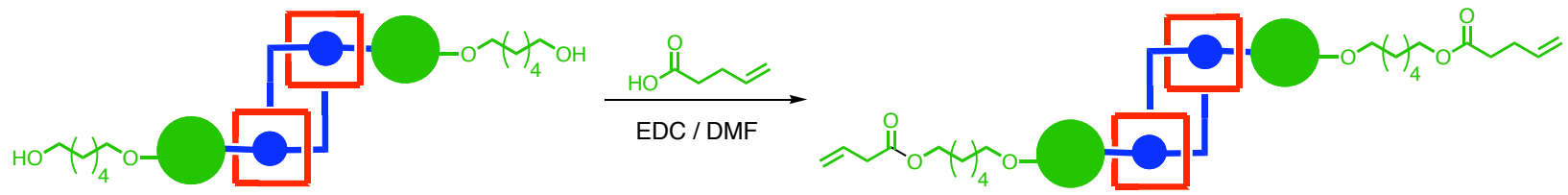

8- $\mathrm{H}_{2} \cdot 2 \mathrm{PF}_{6}$ : EDC (0.64g, 3.35 mmoles $)$, 4-pentenoic acid $(0.34 \mathrm{~g}, 3.35$ mmoles $)$ and DMAP $(0.02 \mathrm{~g}, 0.16$ mmoles) were dissolved in anhydrous DMF $(9 \mathrm{ml}, 0.1 \mathrm{M})$ and stirred at room temperature for 30 minutes. The diol 7- $\mathrm{H}_{2} \cdot 2 \mathrm{PF}_{6}(1.40 \mathrm{~g}, 0.84 \mathrm{mmoles})$ was dissolved in anhydrous DMF (1ml) and added via syringe to the EDC mixture. The reaction was stirred under Ar for 24 hours. The reaction mixture was diluted with brine and ethyl acetate. The aqueous layer was extracted twice with brine. The organic layer was extracted twice with brine and dried over magnesium sulfate. The solvent was removed under reduced pressure and the crude oil was purified by column chromatography $\left(\mathrm{SiO}_{2}\right.$ : methylene chloride/methanol 100:1 gradient to 100:2) to yield the product $8-\mathrm{H}_{2} \cdot 2 \mathrm{PF}_{6}$ as a pale brown foamy solid (1.2 g, $80 \%$ yield). ${ }^{1} \mathrm{H} \mathrm{NMR}\left(300 \mathrm{MHz}, \mathrm{CDCl}_{3}\right): \delta 7.74(\mathrm{br} \mathrm{s}, 4 \mathrm{H}), 7.01-6.91(\mathrm{~m}, 4 \mathrm{H})$, 6.81-6.76 (m, 6H), 5.89-5.76 (m, 2H), 5.09-4.98 (m, 4H), 4.65-4.33 (m, 12H), $4.09(\mathrm{t}, \mathrm{J}=6.9 \mathrm{~Hz}, 8 \mathrm{H})$, $3.98(\mathrm{t}, \mathrm{J}=6.6 \mathrm{~Hz}, 8 \mathrm{H}), 3.83(\mathrm{~s}, 12 \mathrm{H}), 3.76$ (br m, 36H), 2.45-2.34 (m, 8H), 1.83-1.39 (br m, 64H). ${ }^{13} \mathrm{C}$ NMR $\left(75 \mathrm{MHz}, \mathrm{CDCl}_{3}\right): \delta 173.39,173.37,154.21,154.08,146.91,146.42,138.14,136.92,127.28$, $126.89,123.91,123.67,115.65,113.85,112.55,105.09,73.69,73.04,72.71,72.45,72.28,71.55$, 71.06, 70.52, 70.02, 68.67, 68.39, 64.61, 56.58, 52.71, 52.36, 37.77, 30.24, 29.94, 29.77, 29.10, 28.81, 27.94, 27.88, 25.91, 25.83, 25.76, 25.70. HRMS-FAB (m/z): $\left[\mathrm{M}+\mathrm{H}+\mathrm{PF}_{6}\right]$ calcd for $\mathrm{C}_{86} \mathrm{H}_{136} \mathrm{~N}_{2} \mathrm{O}_{22} \mathrm{~F}_{6} \mathrm{P}$, 1693.9227; found, 1693.9293 .

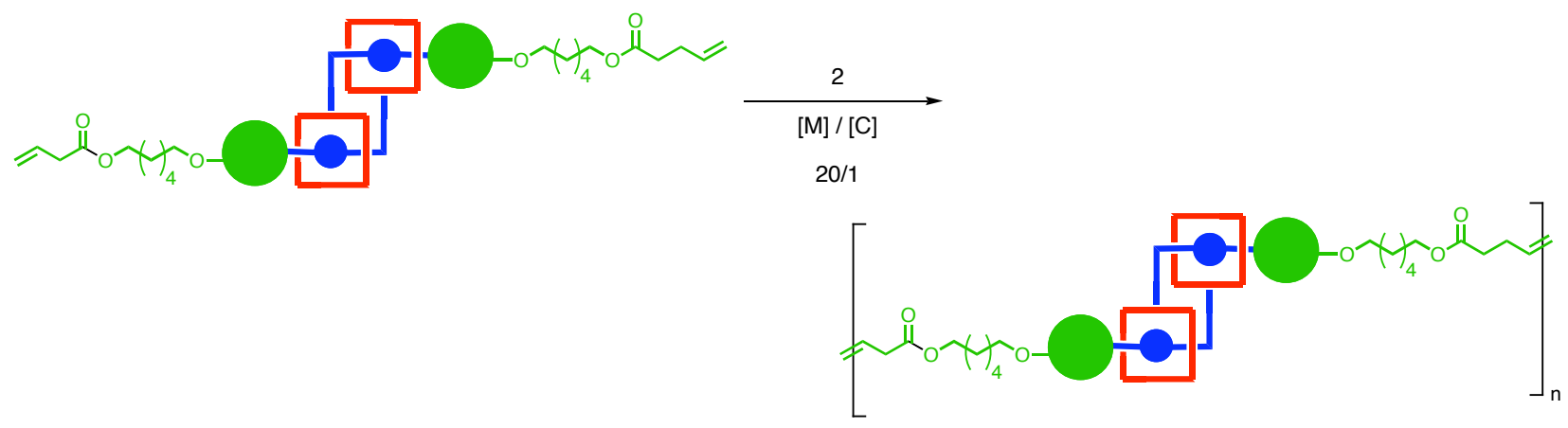

9- $\mathrm{H}_{2 \mathrm{n}} \cdot 2 \mathrm{nPF}_{6}$ : The diene (20.5 mg, $0.01 \mathrm{mmoles}$ ) was dissolved in $1 \mathrm{ml}$ of dry degassed $\mathrm{CH}_{2} \mathrm{Cl}_{2}$ and placed in a schlenk tube with a teflon stopper. Metathesis catalyst $2(0.47 \mathrm{mg}, 0.00005 \mathrm{mmoles})$ was added in $50 \mathrm{uL}$ of $\mathrm{CH}_{2} \mathrm{Cl}_{2}$. The schlenk tube was heated to $40^{\circ} \mathrm{C}$, with a continuous Ar purge until minimal solvent remained (approximately $25 \mathrm{uL}$ - approximately 30 minutes). The teflon stopper was closed, and the heating continued for 24 hours. The polymerization was quenched by adding ethyl vinyl ether. The solvent was removed under reduced pressure. No further purification was performed. ${ }^{1} \mathrm{H}$ NMR (500 MHz, $\mathrm{CDCl}_{3}$ ): $\delta 7.75$ (br s, 4H), 6.99-6.79 (m, 10H), 5.58-5.31 (br m, 2H), 4.65-4.36 (br $\mathrm{m}, 12 \mathrm{H}$ ), 4.14-3.50 (br m, 56H), 2.55-2.21 (br m, 8H), 1.94-1.86 (br m, 64H). $\mathrm{M}_{\mathrm{n}}$ was not able to be determined using GPC due to poor chromatography. Both solvent (THF, DCM, DMF, DMF with 0.1 M LiBr, DMF with $0.1 \mathrm{M} \mathrm{NH}_{4} \mathrm{PF}_{6}$ ) and column types (PLgel 5 um 10E3A size 
exclusion column and PLgel 5um guard column - purchased from polymer laboratories and ViscoGEL I-Series columns, I-MBLMW-3078 and I-MBHMW-3078 - purchased from viscotek) were varied to try and improve chromatography, but with little success. To further confirm the polymerization results observed in the ${ }^{1} \mathrm{H}$ NMR and MALDI, HPLC was employed. HPLC was used to verify polymerization rather than olefin isomerization (which would have similar olefin region in the ${ }^{1} \mathrm{H}$ NMR). Diene 6 has an elution time of 46.876 minutes (steady ramp - $10 \% \mathrm{MeCN}$ in $0.1 \%$ aqueous trifluoroacetic acid to $100 \% \mathrm{MeCN})$. Polymer 7 was placed on the HPLC under identical ramp conditions. Diene 6 had completely disappeared and no new signals were observed over the course of the 90 minute run, indicating that the internal olefin protons observed in the ${ }^{1} \mathrm{H}$ NMR are due to ADMET polymerization rather than olefin isomerization. 
${ }^{1} \mathrm{H}$ NMR compound $\mathbf{1 b}$ :
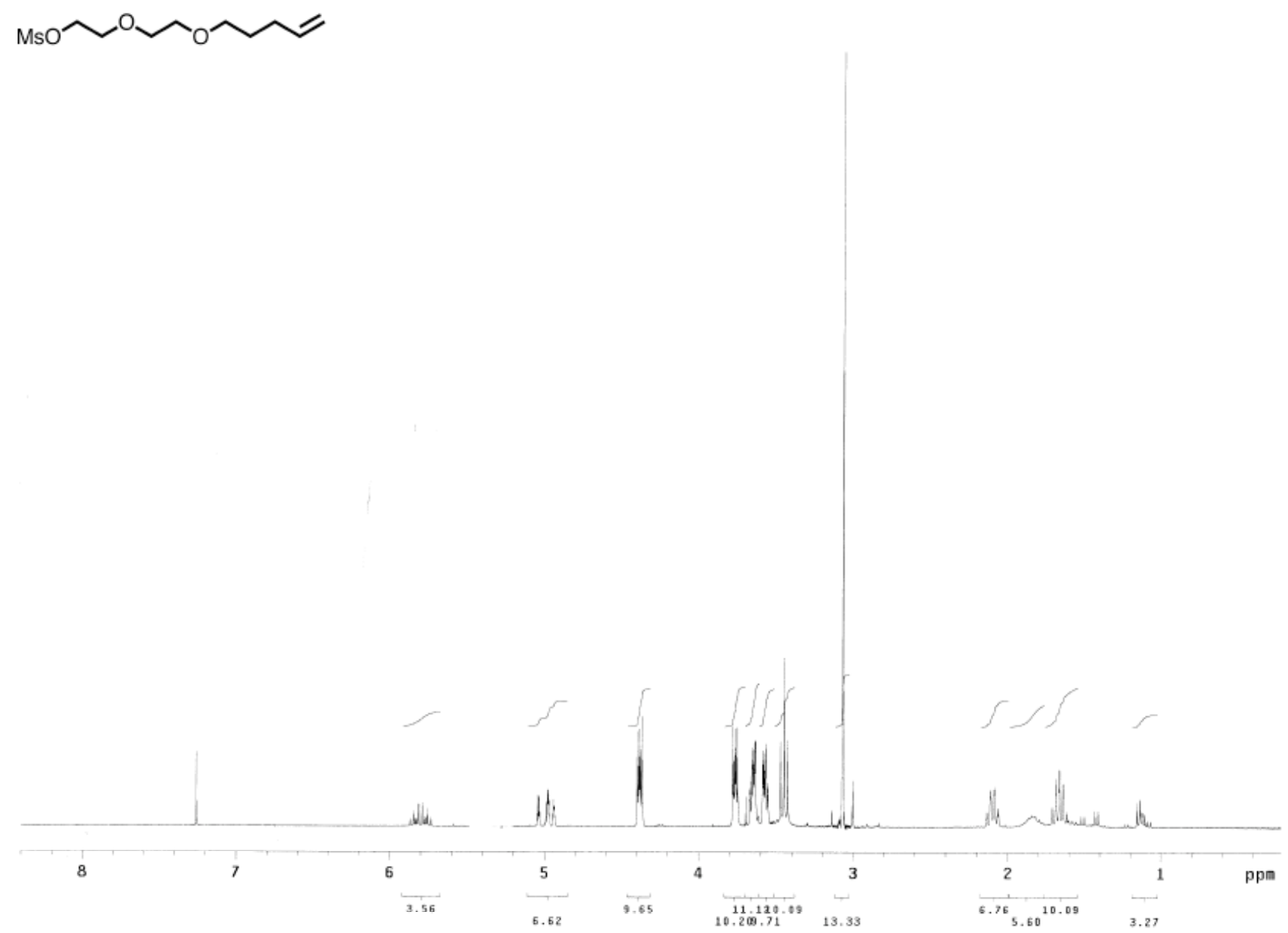
${ }^{1} \mathrm{H}$ NMR compound 1c:

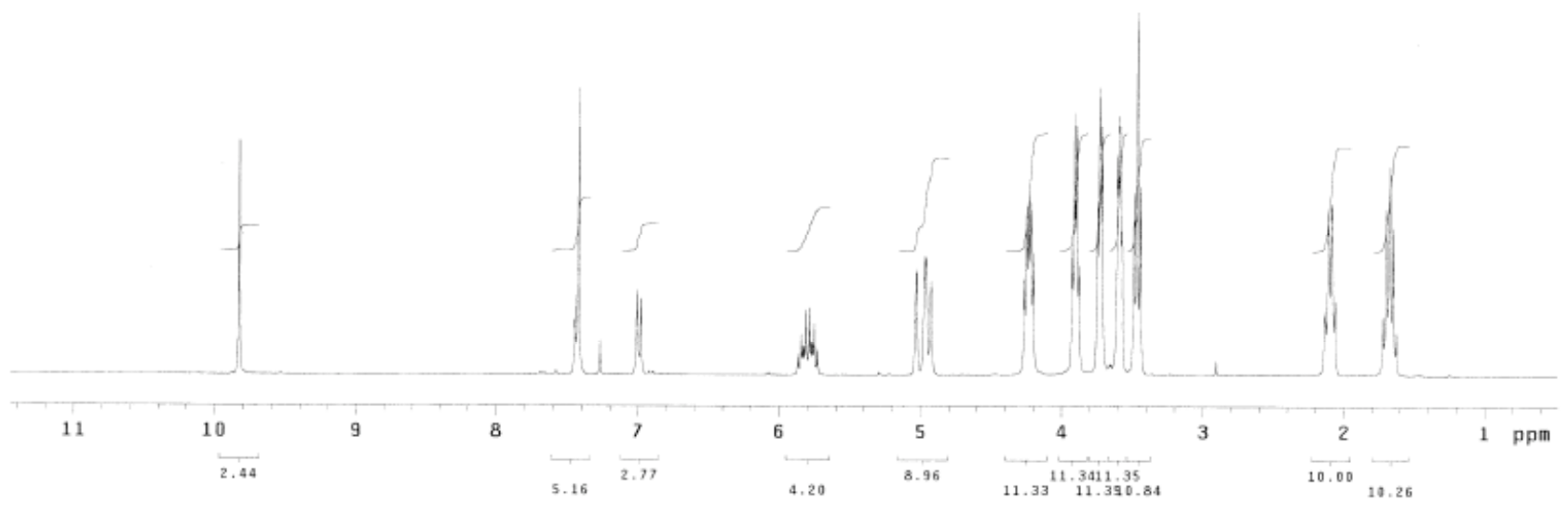


${ }^{13} \mathrm{C}$ NMR compound 1c:

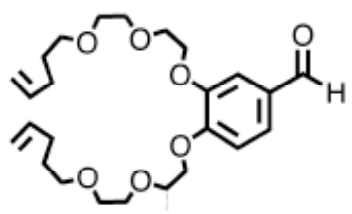

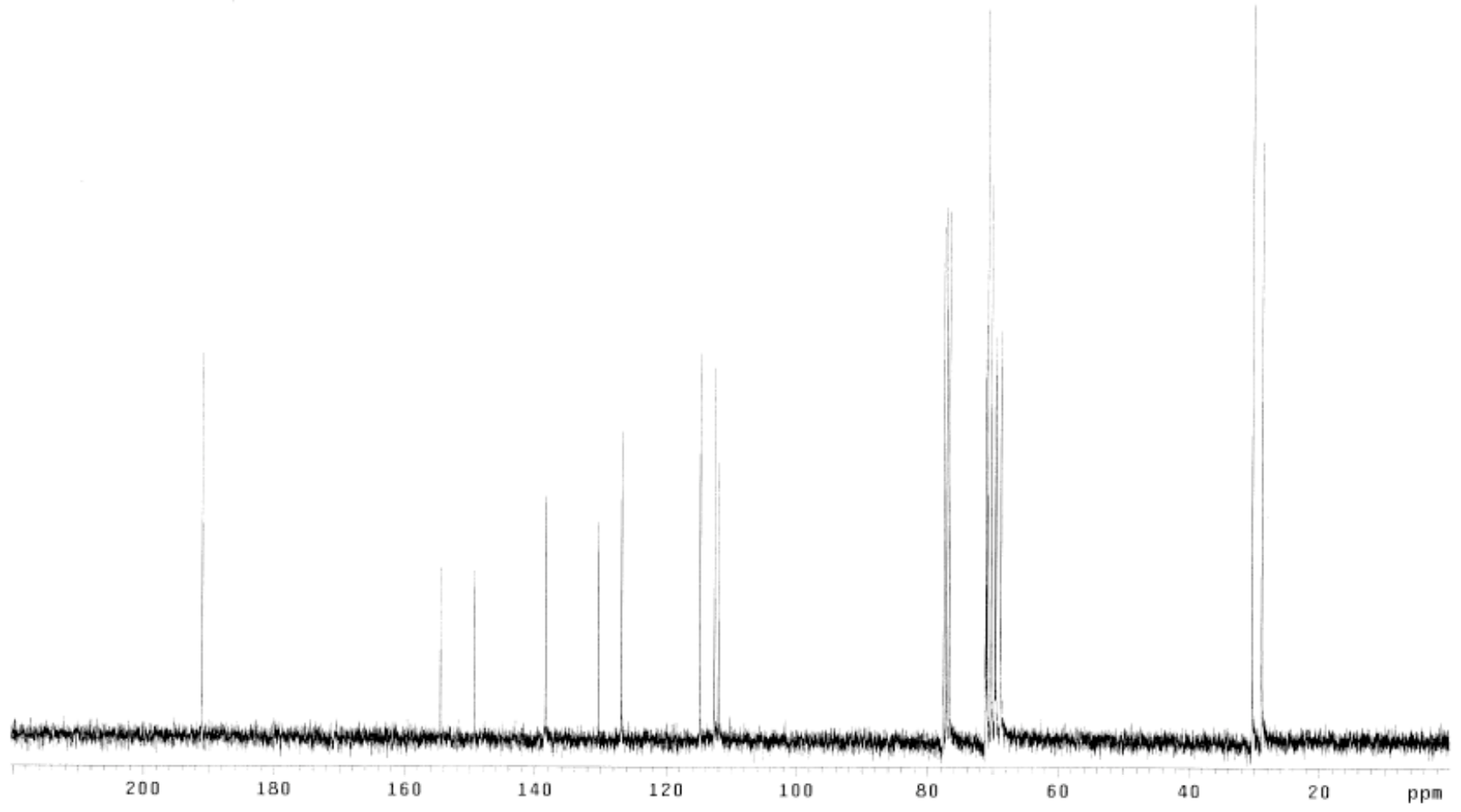


${ }^{1} \mathrm{H}$ NMR compound 1:

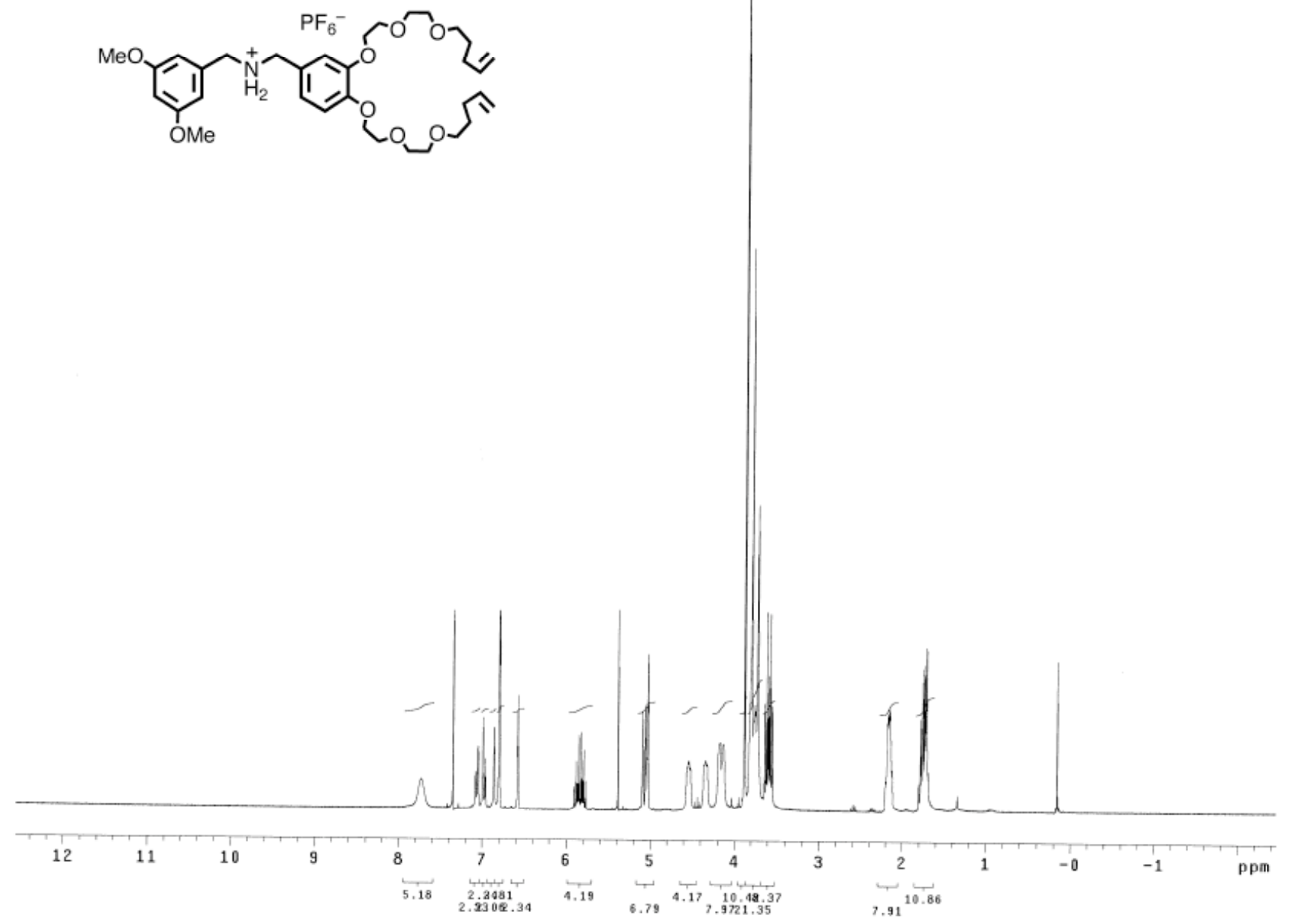


${ }^{13} \mathrm{C}$ NMR compound $\mathbf{1}$ :

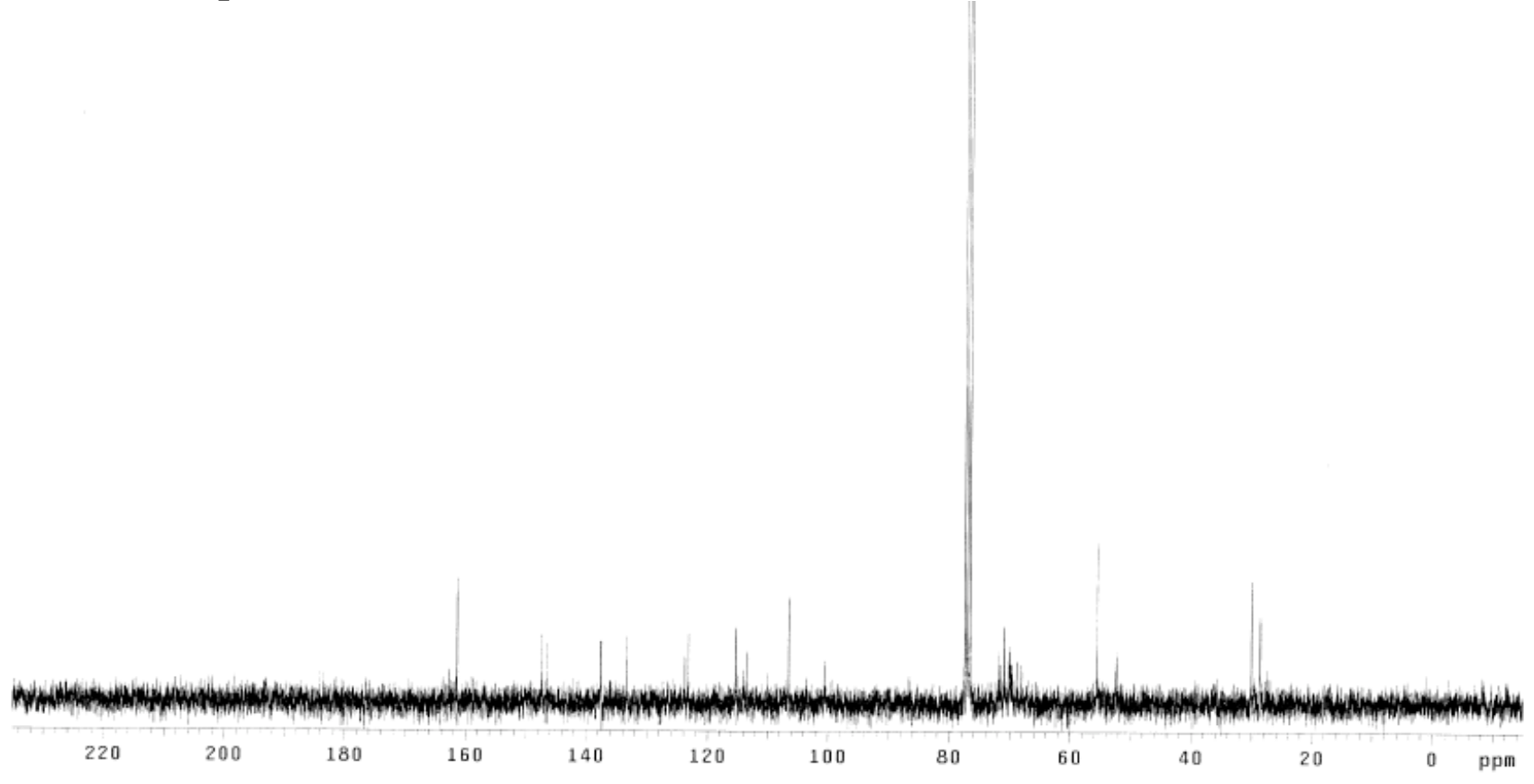


${ }^{1} \mathrm{H}$ NMR compound $\mathbf{3}$ :
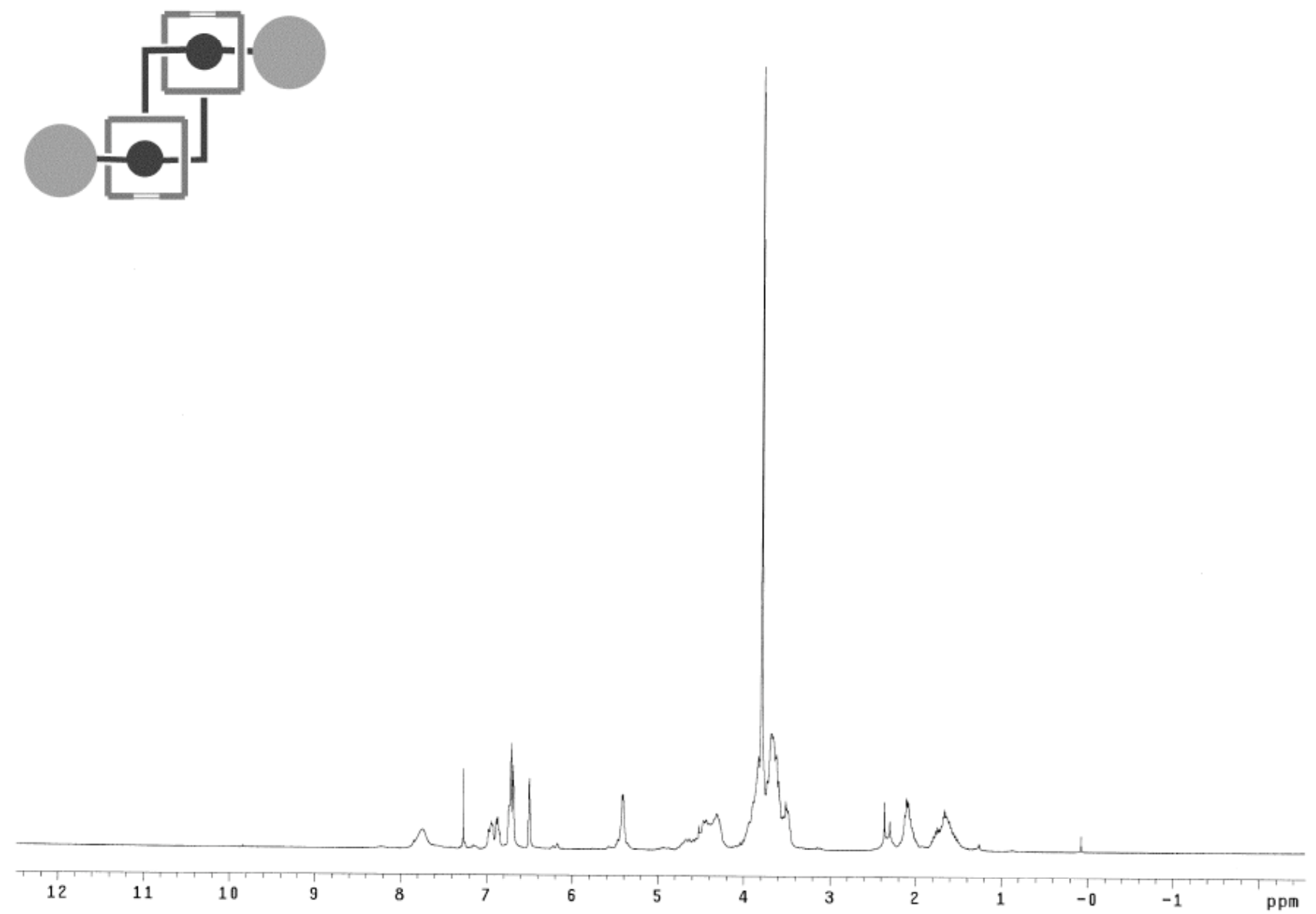
${ }^{1}$ H NMR compound 5a:
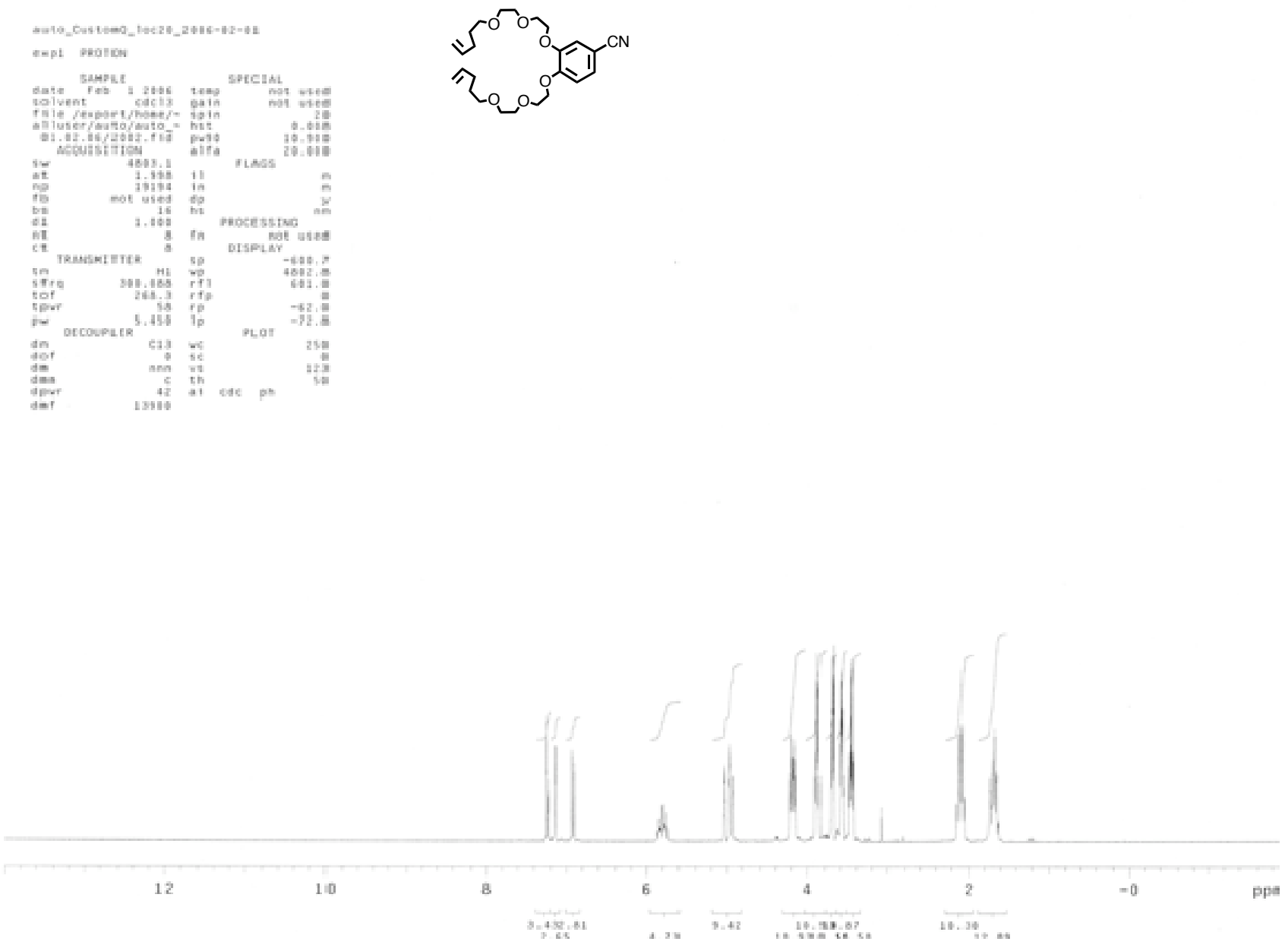
${ }^{13} \mathrm{C}$ NMR compound 5a:

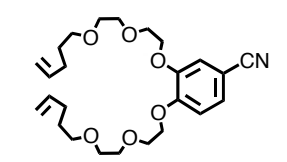

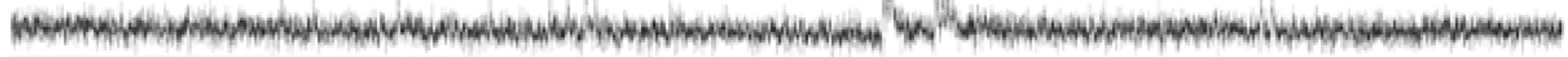

$\begin{array}{llllll}180 & 160 & 180 & 120 & 80 & 60\end{array}$


${ }^{1} \mathrm{H}$ NMR compound $\mathbf{5 b}$ :
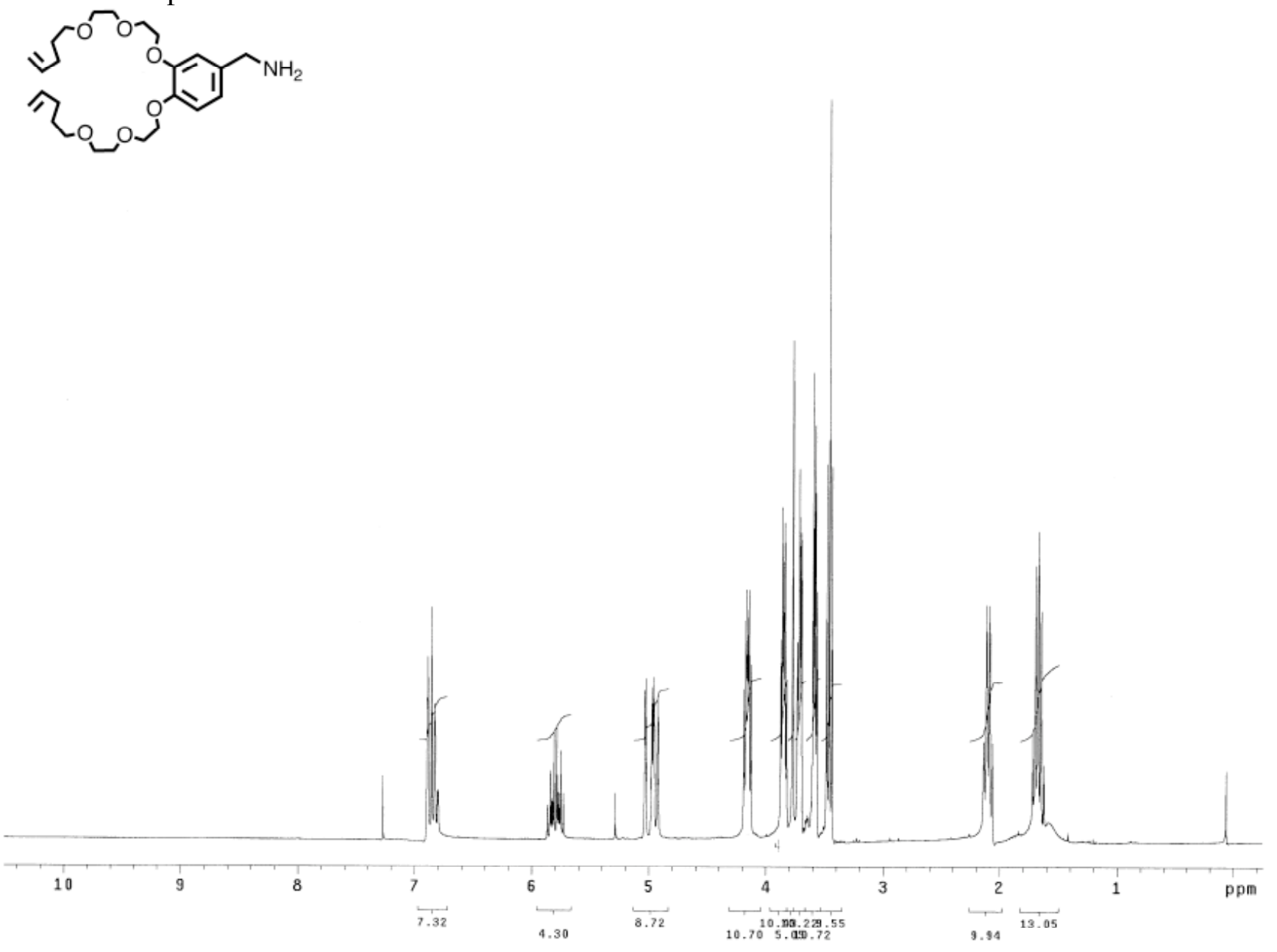
${ }^{13} \mathrm{C}$ NMR compound $\mathbf{5 b}$ :<smiles>C=C/C=C\COCCOCOc1cc(CN)ccc1OCOCOCCC=C</smiles>

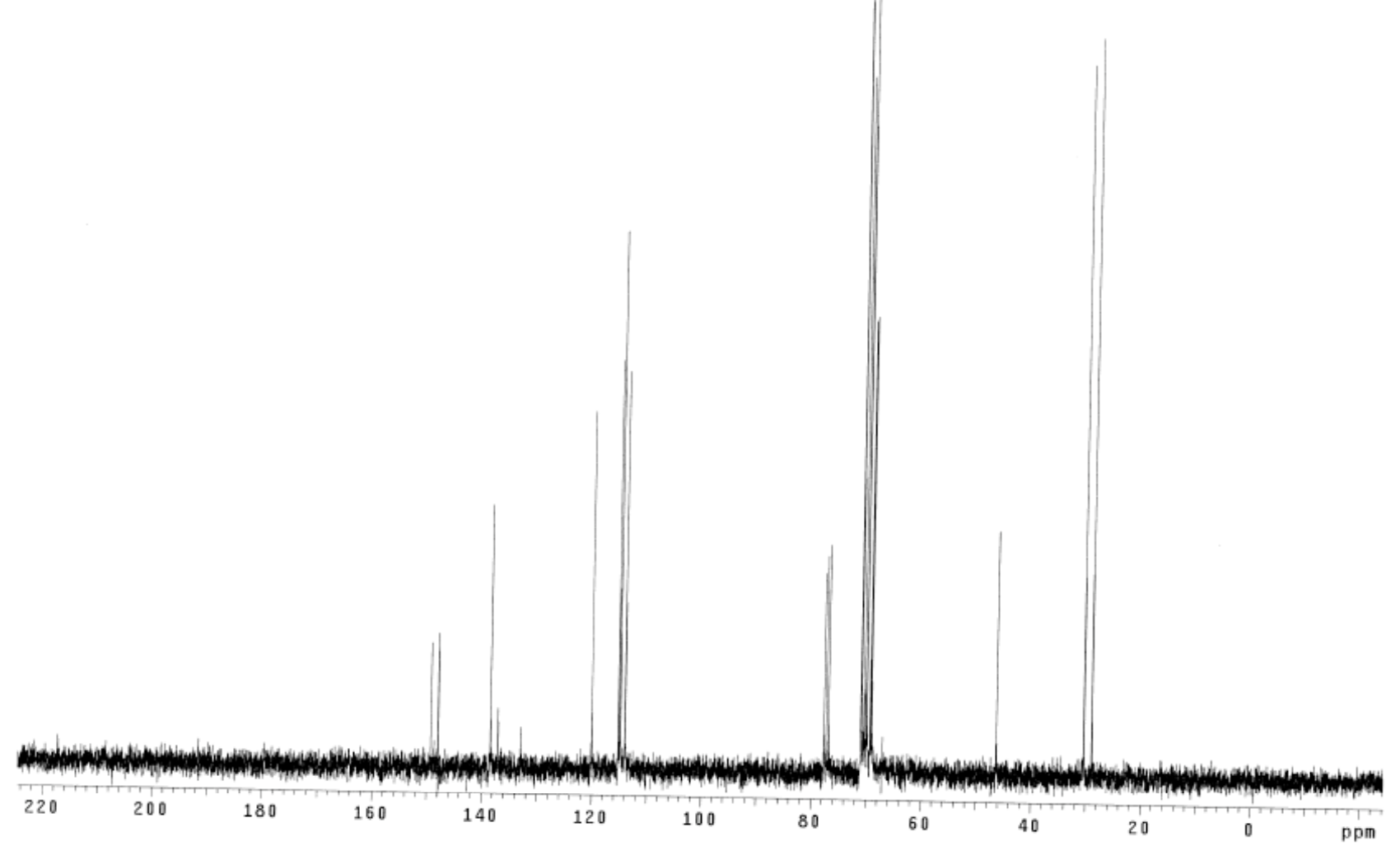


${ }^{1} \mathrm{H}$ NMR compound 5c:<smiles>COc1cc(C=O)cc(OC)c1OCC(C)(C)C(C)(C)CO</smiles>

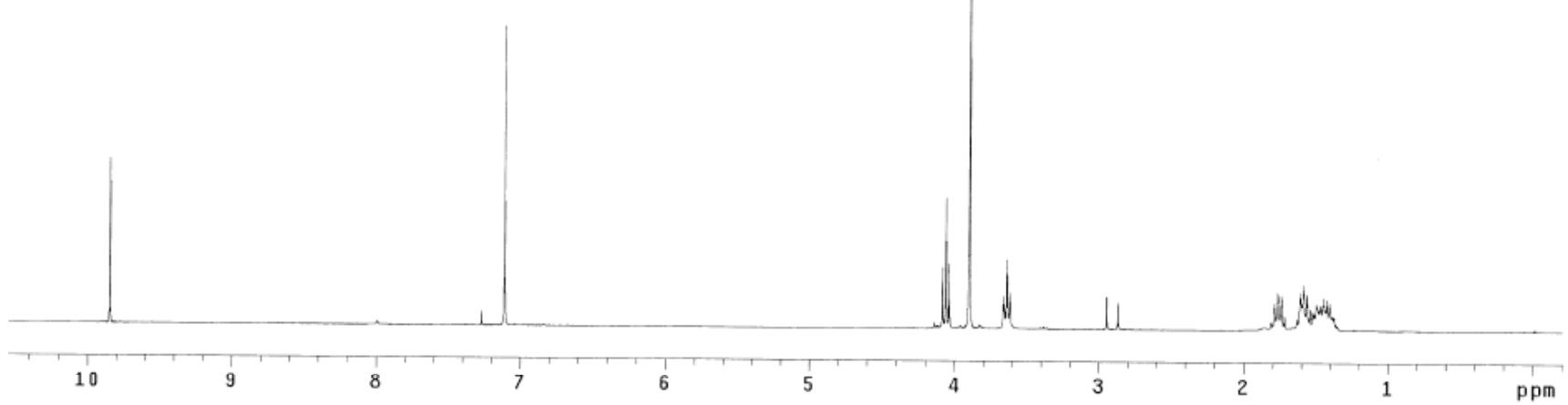


${ }^{13} \mathrm{C}$ NMR compound 5c:<smiles>COc1cc(C=O)cc(OC)c1OCC(C)(C)CO</smiles>

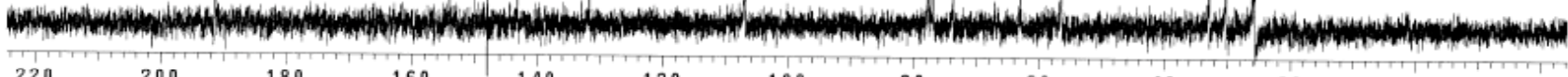


${ }^{1} \mathrm{H}$ NMR compound 5:
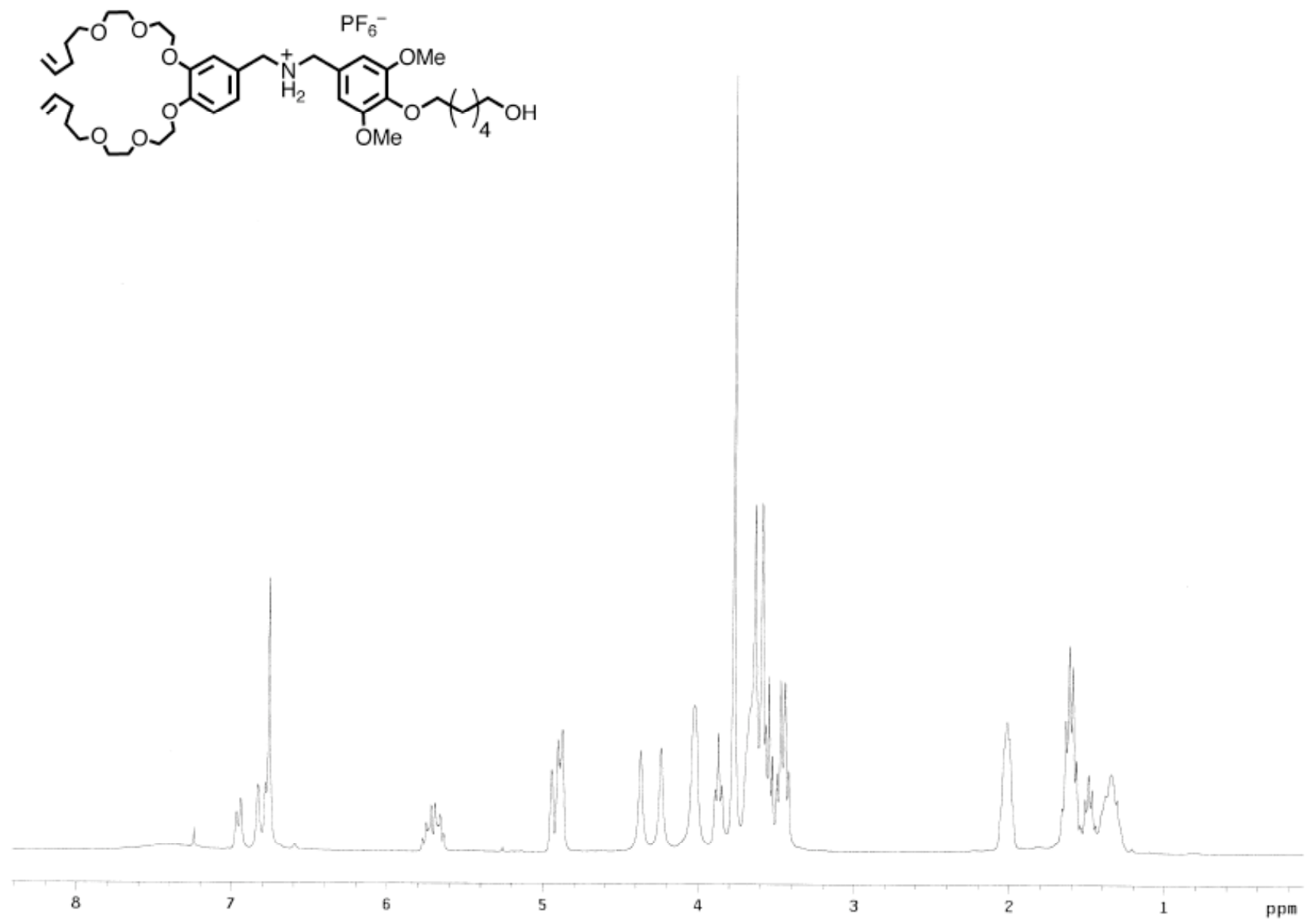
${ }^{13} \mathrm{C}$ NMR compound 5:
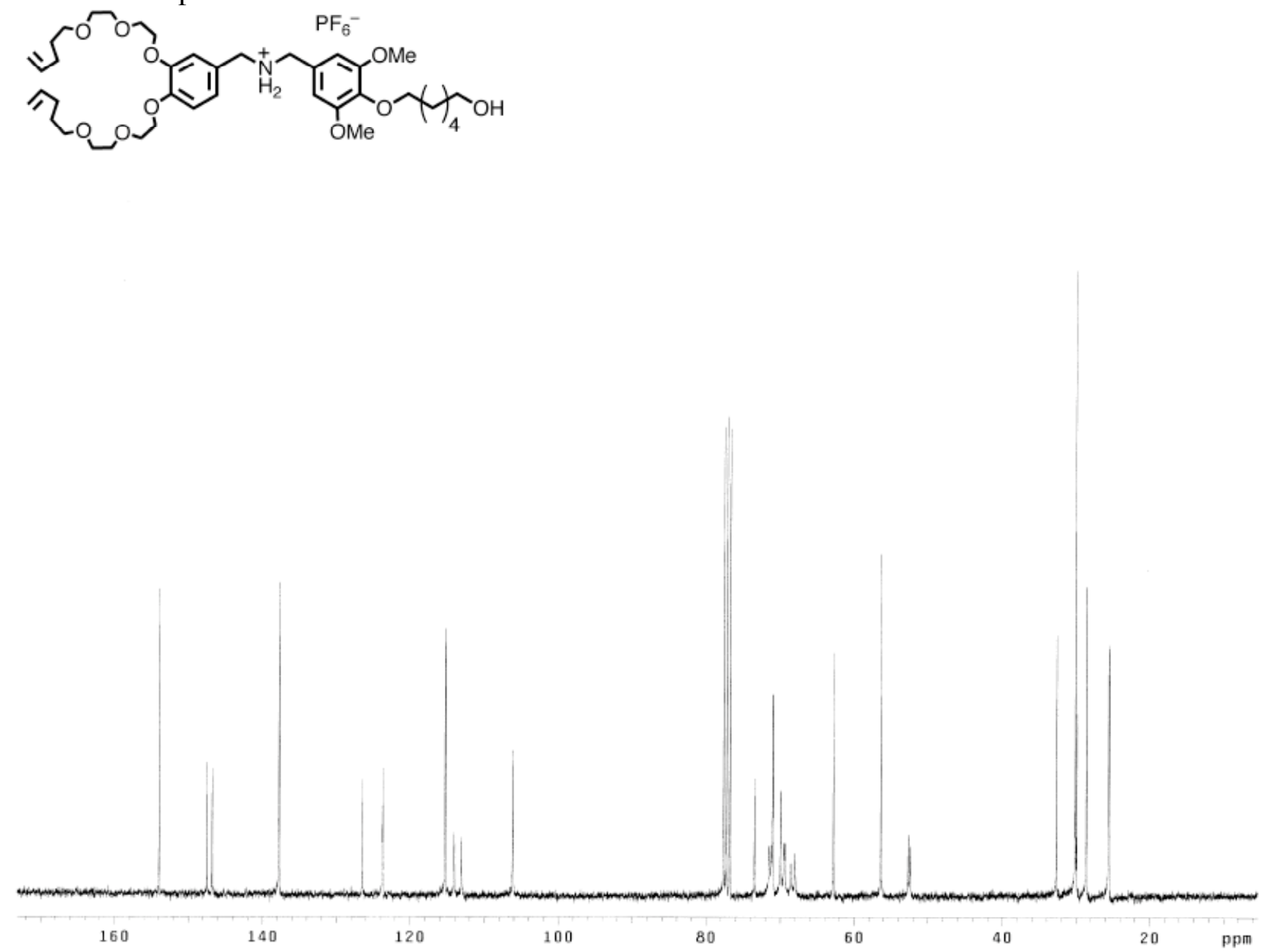
${ }^{1} \mathrm{H}$ NMR compound 6 :

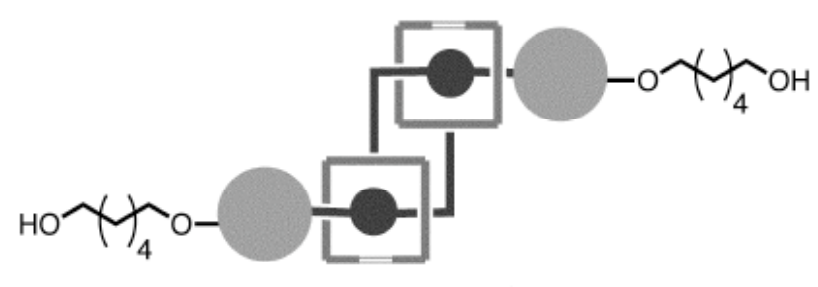


${ }^{13} \mathrm{C}$ NMR compound 6 :
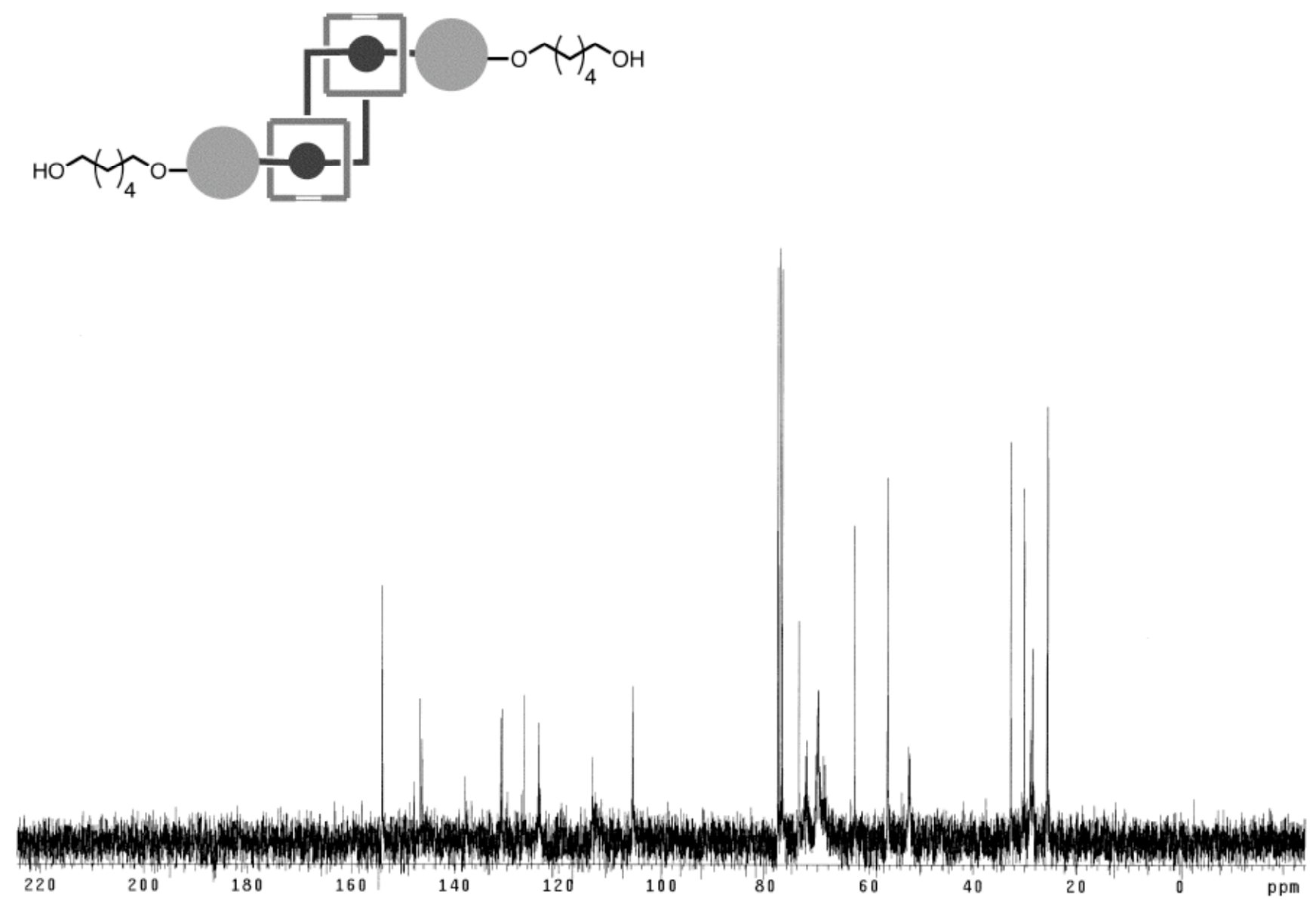
${ }^{1} \mathrm{H}$ NMR compound 7:
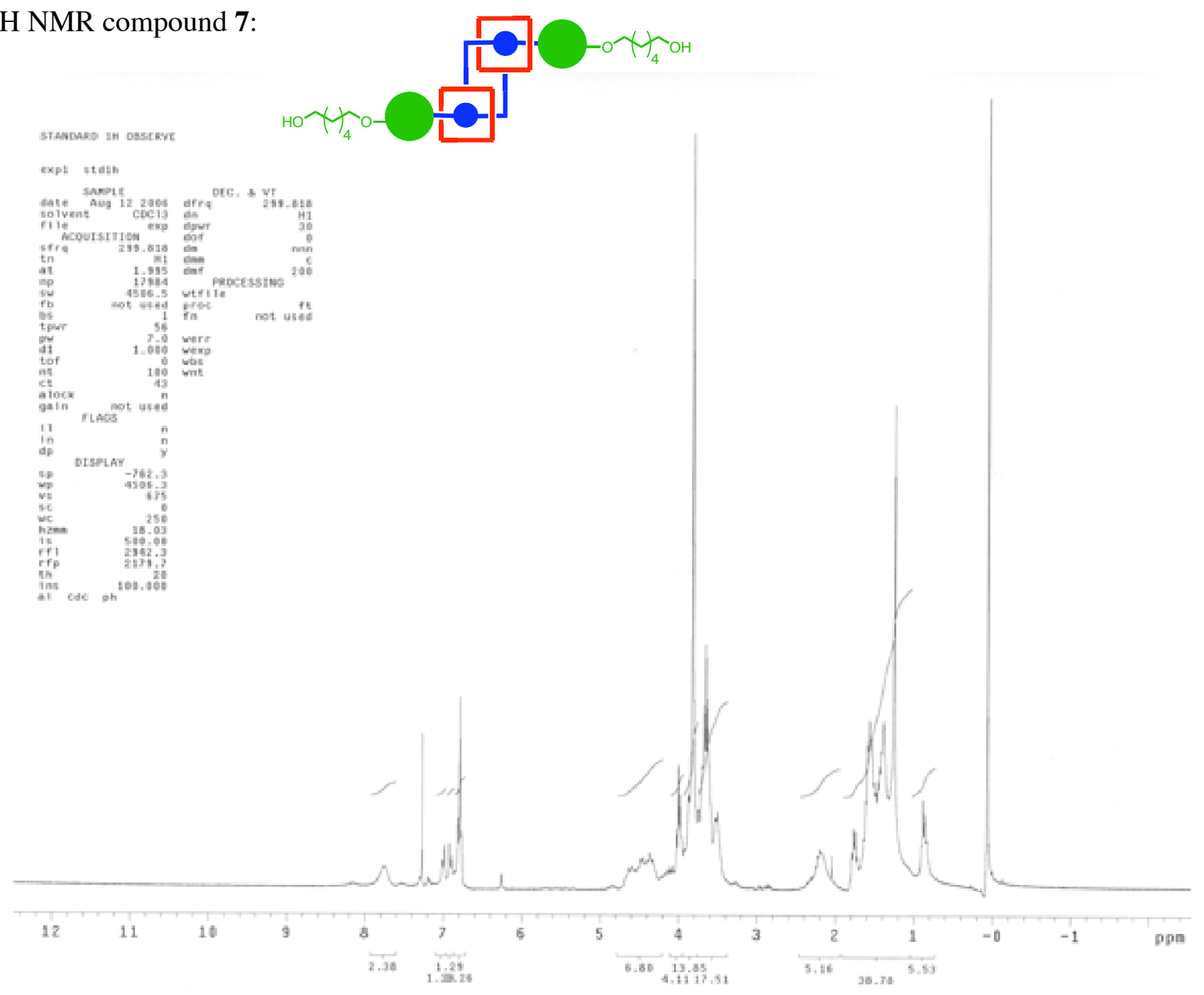
${ }^{13} \mathrm{C}$ NMR compound 7:
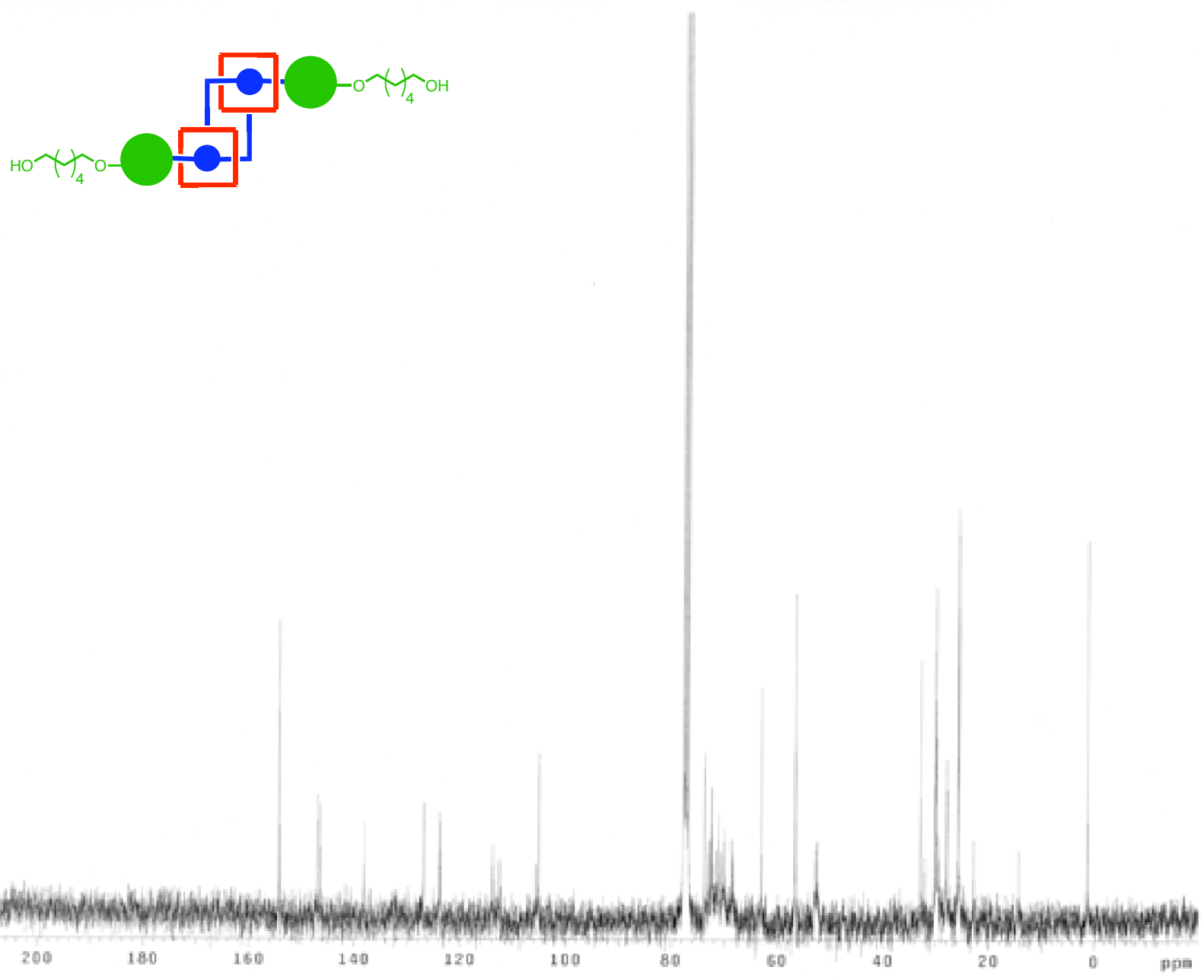
${ }^{1} \mathrm{H}$ NMR compound 8 :
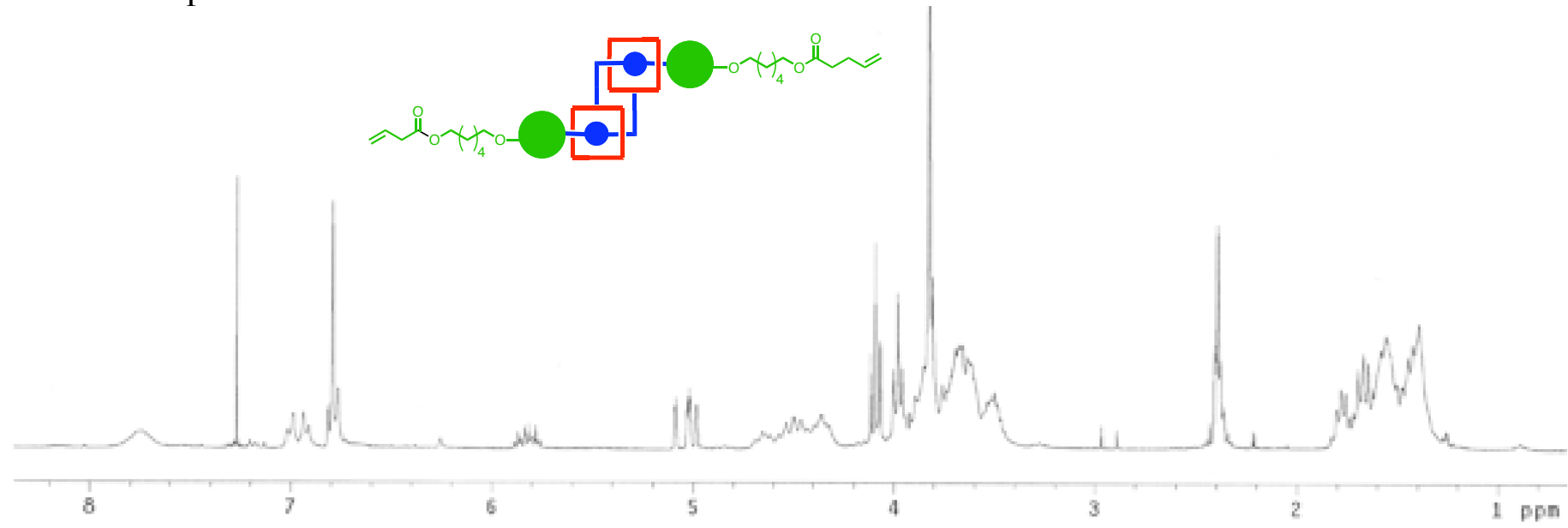

${ }^{13} \mathrm{C}$ NMR compound 8 :
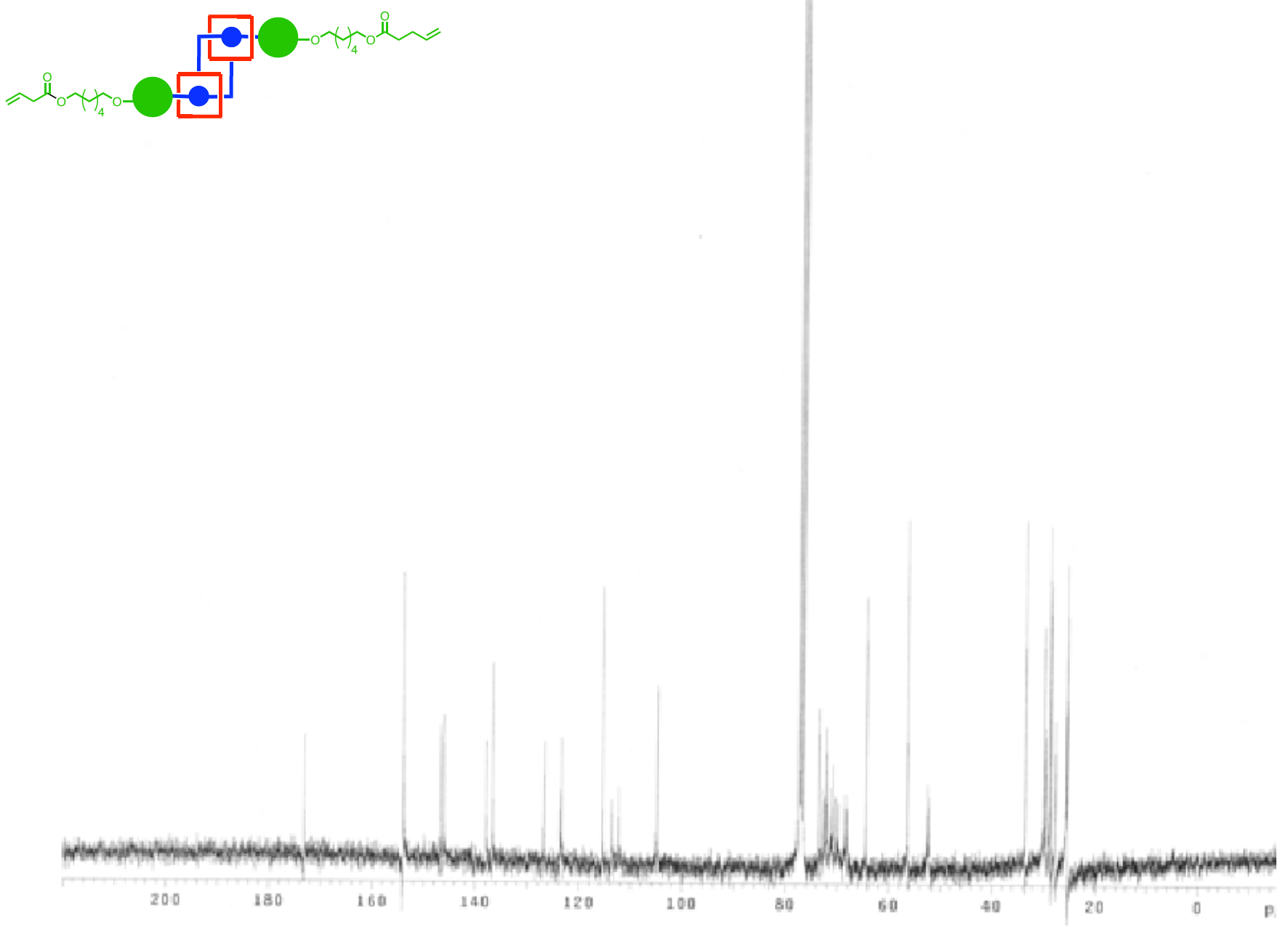


\section{${ }^{1} \mathrm{H}$ NMR compound 9:}

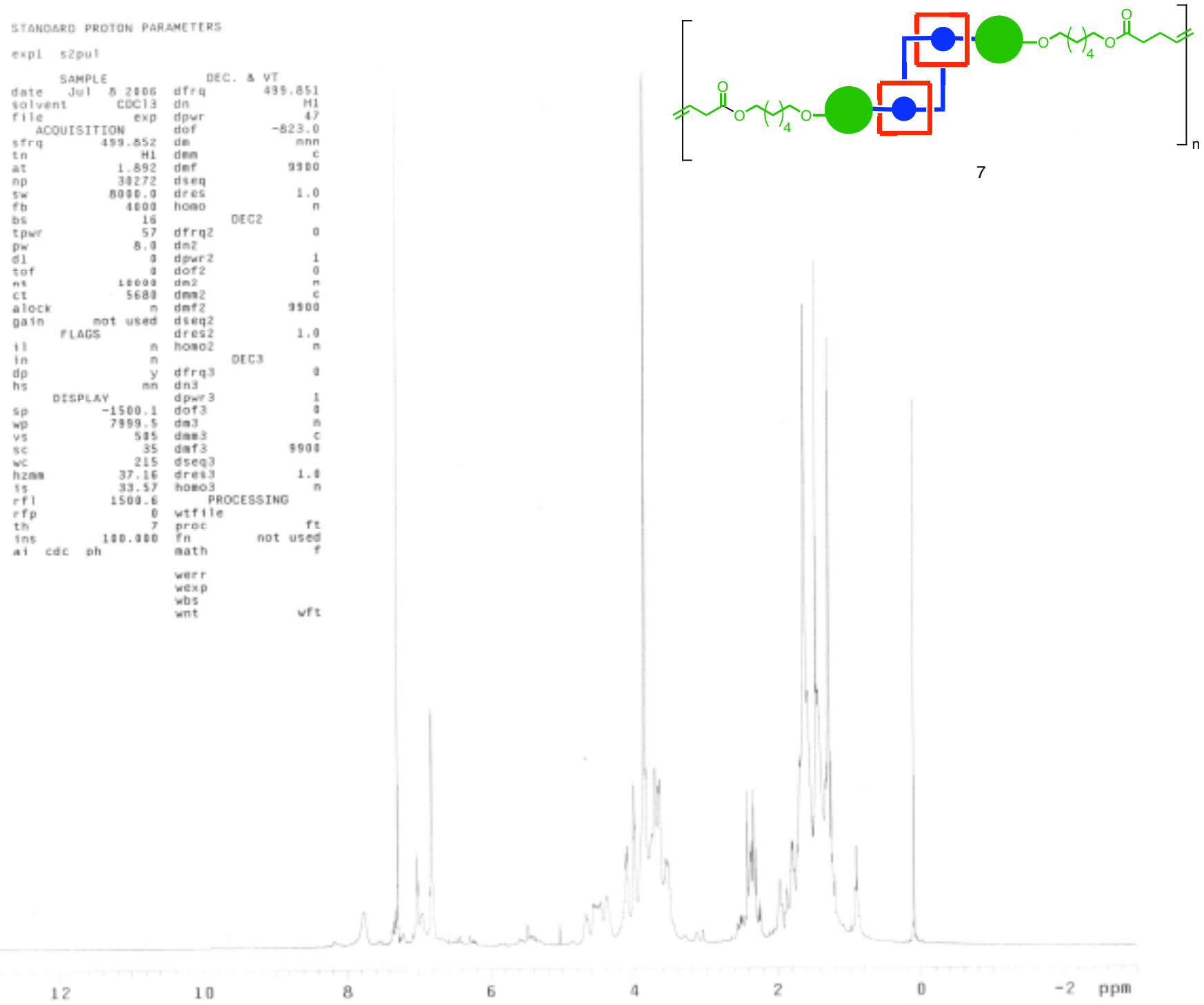

